\title{
PROCJENA DOBIVENIH KNJIŽNIČARSKIH KOMPETENCIJA ZAVRŠENIH STUDENATA INFORMACIJSKIH ZNANOSTI U HRVATSKOJ
}

\author{
ASSESSMENT OF ACQUIRED LIBRARY COMPETENCES \\ FROM THE PERSPECTIVE OF LIS ALUMNI IN CROATIA
}

\author{
Martina Dragija Ivanović \\ Odjel za informacijske znanosti \\ Sveučilište u Zadru \\ mdragija@unizd.hr \\ Boris Badurina \\ Odsjek za informacijske znanosti, Filozofski fakultet \\ Sveučilište u Osijeku \\ boris.badurina@ffos.hr
}

UDK / UDC [02:001.102:004]:[ 005.336.5-

$-057.875](497.5)$

Izvorni znanstveni rad / Original scientific paper

Primljeno / Received: 8. 10. 2019.

Prihvaćeno / Accepted: 6. 10. 2020.

\section{Sažetak}

Cilj. Cilj provedenog istraživanja bio je ispitati u kojoj mjeri studiji informacijskih znanosti / knjižničarstva pripremaju studente za buduće poslove u knjižnicama, odnosno u kojoj mjeri studijski programi, iz perspektive bivših studenata, osiguravaju potrebne kompetencije. To su ujedno i glavna istraživačka pitanja, a pretpostavka od koje se krenulo jest da studiji osiguravaju kompetencije potrebne za knjižničarske poslove, odnosno da ispitanici percipiraju kompetencije koje su dobili na studiju kao odgovarajuće za posao koji obavljaju.

Metodologija. Istraživanje je provedeno metodom ankete. Za potrebe istraživanja pripremljen je mrežni anketni upitnik podijeljen u skupine pitanja: sociodemografski podaci; motivi upisa na studij informacijskih znanosti/knjižničarstva; podaci o zapo-

Vjesnik bibliotekara Hrvatske 63, 1-2(2020), 703-746 ISSN 0507-1925 
slenju; procjena kompetencija stečenih na studiju; alumni-mreža; studentska praksa; članstvo i aktivnost u stručnim udruženjima. Upitnik je distribuiran alumni-klubovima, odnosno putem osobnih poznanstava bivših studenata.

Rezultati. Rezultati istraživanja ukazuju da je ukupna procjena dobivenih kompetencija ispitanika na studijima informacijskih znanosti/knjižničarstva relativno niska. Pojedine stavke, poput prakse, ocijenjene su i negativno, što ukazuje na nezadovoljstvo pojedinim aspektima studija. S druge strane motivi upisa studenata na studije informacijskih znanosti/knjižničarstva većinom su pozitivni u smislu da su uglavnom upisivali studij u području kojim se žele baviti. Također zadovoljstvo poslom relativno je visoko.

Ograničenja. Rezultati istraživanja ukazuju na raskorak između ishoda učenja i kompetencija koje se očekuju da će ih studenti imati završetkom studija i percepcije studenata o razini dobivenih kompetencija. No istraživanjem nije obuhvaćen aspekt ispitanikovih očekivanja. Osim toga provedeno istraživanje nije uzelo u obzir uspješnost studenata tijekom studija, što može biti dodatni čimbenik u stvaranju raskoraka.

Originalnost. Provedeno istraživanje ukazuje na potencijalni problem u pojedinim segmentima studijskih programa studija informacijskih znanosti/knjižničarstva obuhvaćenih istraživanjem. Rezultati mogu poslužiti za eliminaciju uočenih problema

Ključne riječi: informacijske znanosti, ishodi učenja, knjižničarstvo, kompetencije

\section{Abstact}

Goal. The goal of the research presented in this paper was to analyse to what degree the LIS programmes prepare students for the future work in libraries. Furthermore, to what degree do the LIS programmes ensure the necessary competences from the perspective of the LIS alumni. These are also the two research questions, and the main hypothesis examins whether the respondents perceive the acquired competencies as adequate for their everyday work.

Methodology. The research was conducted by an online survey. The questionnaire was divided into several groups of questions: demographics, motivation for enrolment, perception of the acquired competences, alumni network, practical training, membership and activity in library associations. The questionnaire was distributed through the alumni network and personal contacts.

Results. The research results show that the overall perception of the acquired competences through the Croatian LIS studies is relatively low. Some of the elements like practical training are marked negatively which indicates low satisfaction with certain aspects of the LIS programmes. On the other hand, the enrolment motivation is generally positively assessed, meaning that the respondents had enrolled into the programmes in the field they wanted to pursue jobs in the future. The job satisfaction is also assessed as relatively high. 
Limitations. The results show possible discrepancies between the expected learning outcomes and competences and the students' perception of the acquired competences. It must be mentioned that the research questions did not include the respondents expectations aspect. Also, the students' accomplishments during the studies had not been taken into account, and that could be one of the factors that generated the discrepancies.

Originality. The research results point to potential problems in certain segments of the existing LIS programmes in Croatia, and they could help in elimination or dealing with these problems.

Keywords: competences, information science, learning outcomes, librarianship

\section{Uvod}

U praksi, pri izradi studijskih programa nastavnici na sveučilištima neminovno se susreću s pitanjem koje su to vještine i znanja potrebni studentima da se što brže i jednostavnije uklope na tržište rada nakon završenog školovanja. Istraživanja motivacije upisa i odabira studija te zadovoljstva studenata studijem čimbenici su kvalitete studija. Cilj svake visokoškolske ustanove jest unaprijediti svoje studijske programe, znanstvene i nastavne procese i aktivnosti. Jedna od promjena koje su se dogodile uvođenjem Bolonjskog procesa na hrvatskim sveučilištima jest $\mathrm{i}$ uvođenje niza aktivnosti usmjerenih prema mjerenju kvalitete studijskih programa. Sveučilišta i visoka učilišta morala su osigurati sustav osiguravanja kvalitete koji je bio definiran pravilnikom o sustavu osiguravanja kvalitete. Kao što je navedeno u Priručniku kvalitete na Sveučilištu u Zadru ${ }^{1}$,

„cilj osiguravanja i unaprjeđivanja kvalitete je sustavno unaprjeđivanje svih aspekata znanstvenog, nastavnog, stručnog i administrativnog rada u svrhu promicanja visokih standarda profesionalnog i stručnog razvoja svih sudionika u njihovu djelovanju."

Agencija za visoku znanost i obrazovanje ${ }^{2}$ predviđa u svojem dokumentu Provjera osiguranja kvalitete na visokim učilištima (Rujan 2007, AZVO) te u Pravilniku o mjerilima i kriterijima za vrednovanje kvalitete $i$ učinkovitosti visokih učilišta i studijskih programa ${ }^{3}$ u članku 4. Sadržaj vrednovanja, alineja 5., kontakte s bivšim studentima

1 Priručnik kvalitete na Sveučilištu u Zadru (Zadar, 2012). [citirano: 2019-09-15.]. Dostupno na: www.unizd.hr/Portals/0/kvaliteta/Priručnik_kvalitete.pdf

2 Provjera osiguranja kvalitete na visokim učilištima [citirano: 2019-09-10.] Dostupno na: http:// forum.azvo.hr/cd/LinkedDocuments/AZVO_Provjera_osiguranja_kvalitete_Petrovic\%20-\%20 presentation.pdf

3 Pravilinik o mjerilima i kriterijima za vrednovanje kvalitete i učinkovitosti visokih učilišta i studijskih programa. // Narodne novine 9, 139(2005). [citirano: 2019-09-15.]. Dostupno na: https://narodne-novine.nn.hr/clanci/sluzbeni/2005_01_9_139.html 
(alumnijima), što zapravo podrazumijeva povratne informacije završenih studenata (alumnija). U aktima alumni-klubova Filozofskog fakulteta u Osijeku, Filozofskog fakulteta u Zagrebu i Sveučilišta u Zadru navodi se da je jedan od ciljeva Alumni kluba „izgradnja i jačanje veza i suradnje između bivših studenata i Sveučilišta u Zadru“4, suradnja s institucijama u kojima su zaposleni ${ }^{5}$, skrb za razvitak i napredak Fakulteta. ${ }^{6}$ Iskustva bivših studenata na tržištu, a napose njihovo mišljenje o studiju i odnosu znanja i vještina koje su dobili tijekom studija i njihova iskoristivost u svakodnevnim radnim zadacima i daljnjem stručnom i znanstvenom radu, neophodni su za unapređenje bilo kojeg studijskog programa, a time i struke u cjelini.

Općenito gledajući, ciljevi svakog studijskog programa i ishodi učenja osnova su za razumijevanje studijskih programa na relaciji poslodavac-odsjek/odjel/ fakultet. U literaturi postoji velik broj definicija da učenja, a za potrebe ovoga rada uporabljeni su materijali koji se nalaze u Javnoj dokumentaciji usluga SRCA (Merlin 17/18 Ishodi učenja - Centar za e-učenje - wiki.srce.hr) u kojima se ishodi učenja definiraju kao tvrdnje koje opisuju što student treba znati, razumjeti ili moći napraviti na kraju kolegija ili određenog razdoblja učenja, a postizanjem ishoda učenja studenti stječu kompetencije za zapošljavanje. ${ }^{7}$

Ta definicija ishoda učenja potrebna je za razumijevanje ishoda učenja koji se nalaze u programima studija Odsjeka za informacijske i komunikacijske znanosti u Zagrebu, Odjela za informacijske znanosti u Zadru i Odsjeka za informacijske znanosti u Osijeku, odjela, odnosno odsjeka koji su uključeni u istraživanje koje će biti predstavljeno u ovome radu. Ciljevi i ishodi učenja predstavljeni u radu obuhvaćaju kako diplomsku tako i preddiplomsku razinu.

\section{Kompetencije u studijskim programima izobrazbe knjižničara}

U pogledu kompetencija u studijskim programima izobrazbe knjižničara, u Hrvatskoj su napravljeni prvi koraci za usklađivanje kompetencija na razini države. Još 2009. godine proveden je projekt „Cjeloživotno učenje knjižničara: ishodi učenja i fleksibilnost“. Bio je to jednogodišnji projekt Nacionalne i sveučilišne knjižnice u Zagrebu, Odsjeka za informacijske i komunikacijske znanosti Filozofskog fakulteta Sveučilišta u Zagrebu, Knjižnica grada Zagreba i Hrvatskog knjižničarskog društva. ${ }^{8,9}$

\footnotetext{
4 Statut Alumni kluba Sveučilišta u Zadru. [citirano: 2019-09-15.]. Dostupno na: http://www. unizd.hr/Portals/0/alumni_klub/Statut_Alumni_kluba.pdf?ver=2014-12-10-133738-453

5 Alumni. [citirano: 2019-09-15.]. Dostupno na: www.ffos.unios.hr/infoznanosti/alumni

6 Alumni Filozofskog fakulteta. [citirano: 2019-09-15.]. Dostupno: http://www.ffzg.org.

7 Merlin 17/18 Ishodi učenja. [citirano: 2019-09-17.]. Dostupno na: https://wiki.srce.hr/pages/ viewpage.action?pageId=10551508.

8 CUK: cjeloživotno učenje knjižničara: ishodi učenja i fleksibilnosti. [citirano: 2019-09-17.]. Dostupno na: http://www.nsk.hr/cuk/index.htm.

9 Projekt je odobren 2008. godine na natječaju „Reforma visokog školstva temeljem ishoda učenja“ Nacionalne zaklade za znanost, visoko školstvo i tehnologijski razvoj Republike Hrvatske.
} 
Cilj projekta bila je inicijalna izrada kompetencijskog profila knjižničarske struke u Hrvatskoj. Već tada Ana Barbarić ${ }^{10}$ skrenula je pozornost na postojanje Hrvatskog kvalifikacijskog okvira ${ }^{11}$ koji nas obvezuje da kao struka moramo odrediti koje su to jezgrene kompetencije i kompetencijski profil. ${ }^{12} \mathrm{Na}$ mrežnom mjestu Hrvatskog kvalifikacijskog okvira navodi se:

„Hrvatski kvalifikacijski okvir (HKO) je instrument za ostvarivanje strateških ciljeva kvalitetnog obrazovanja, relevantnog u odnosu na potrebe tržišta rada, pojedinca i društva u cjelini“" ${ }^{13}$

Upravo zbog navedenog važno je u kontekstu ovoga rada razumjeti zašto je važno razmišljati o ishodima učenja te kompetencijama koje studenti dobivaju tijekom studija s jedne strane i tržišta na koje nakon završetka obrazovanja ulaze s druge strane. Kvalifikacije se definiraju kao „objedinjeni skupovi ishoda učenja određenih razina, obujma, profila, vrste i kvalitete. "14 Hrvatski kvalifikacijski okvir dio je Europskog kvalifikacijskog okvira kojemu je cilj

„prepoznavanja razina stečenih kvalifikacija europskih zemalja na osnovi mjerljiva ishoda učenja, međusobnog povjerenja i sustava osiguranja i upravljanja kvalitetom“. ${ }^{15}$

U citiranom dokumentu nalazi se tablica „,bitnih ishoda učenja pojedinih razina kvalifikacijskog okvira“. ${ }^{16}$

Autorica Dijana Machala ${ }^{17}$ provela je nekoliko istraživanja koja su se bavila ishodima učenja studenata informacijskih znanosti i koja u ovom radu rabimo kao teorijsku i istraživačku podlogu. Istraživanje o ishodima učenja diplomiranih knjižničara provele su autorice Kornelija Petr Balog i Ivana Martinović. ${ }^{18}$ Cilj istraživanja koje je 2009. i 2011. godine provela Machala bio je ispitati stavove

10 Barbarić, A. Knjižničarske kompetencije. // Cjeloživotno učenje knjižničara: ishodi učenja i fleksibilnost / urednica Aleksandre Horvat i Dijane Machale. Zagreb: Nacionalna i sveučilina knjižnica. Str. 57-58. [citirano: 2019-09-20.] Dostupno i na: http://www.nsk.hr/cuk/cuk.pdf.

11 Hrvatski kvalifikacijski okvir (HKO). [citirano: 2019-09-20.]. Dostupno na: https://www. azvo.hr/hr/ured-enic-naric/hrvatski-kvalifikacijski-okvir-hko

12 Barbarić, A. Nav.dj., str. 57.

13 Smjernice za razvoj standarda kvalifikacija. [citirano: 2019-09-20.]. Dostupno na: http:// www.kvalifikacije.hr/sites/default/files/documents-publications/2019-08/Smjernice\%20za\%20 razvoj\%20standarda\%20kvalifikacija.pdf

14 Isto.

15 Lončar-Vicković, S.; Z. Dolaček-Alduk. Ishodi učenja: priručnik za sveučilišne nastavnike. Osijek: Sveučilište Josipa Jurja Strossmayera, 2009. Str. 14 [citirano: 2019-09-20.]. Dostupno na: https://www.azoo.hr/images/natjecanja_2014./ishodi_ucenja.pdf.

16 Isto, str. 16.

17 Machala, D. Knjižničarske kompetencije: pogled na razvoj profesije. Zagreb: Hrvatska sveučilišna naklada: Nacionalna i sveučilišna knjižnica, 2015.

18 Petr Balog, K.; I. Martinović. Na tragu ishoda učenja: kompetencije diplomiranih knjižničara Odsjeka za informacijske znanosti u Osijeku. // Vjesnik bibliotekara Hrvatske 52, 1/4(2009), str. 
knjižničara, voditelja knjižnica i profesora knjižnične i informacijske znanosti na tri hrvatska sveučilišta o važnosti i razini usvojenosti područnospecifičnih i generičkih kompetencija kod novodiplomiranih knjižničara po završetku studija. Popis spomenutih područnospecifičnih i generičkih kompetencija vidljiv je u tablicama 12. i 13. To istraživnje posebno je zanimljivo zbog diskrepancije mišljenja ravnatelja knjižnica i knjižničara praktičara $\mathrm{s}$ jedne strane te profesora $\mathrm{s}$ druge strane o važnosti pojedinih kompetencija za struku ${ }^{19}$. Do sličnih spoznaja došle su i Petr Balog i Martinović. Naime njihovo istraživanje pokazalo je da postoje kompetencije koje poslodavci visoko vrednuju, a koje nisu dovoljno prisutne u programu Odsjeka za informacijske znanosti u Osijeku. ${ }^{20,21}$ Diplomski rad Tamare Jozinović2 ${ }^{22}$, obranjen na Odsjeku za informacijske znanosti u Osijeku, bavio se spremnošću magistara informatologije koji su završili studij informacijskih znanosti ili knjižničarstva na Odsjeku za informacijske znanosti u Osijeku za tržište rada. Rezultati upućuju na zaključak kako su bivši studenti, općenito gledajući, zadovoljni stečenim znanjem, ali i da postoje područja koja su u programima od strane ispitanika ocijenjena nižim ocjenama. ${ }^{23}$ Do sličnog zaključka došlo se i u istraživanju provedenog na studentima informacijskih znanosti na Sveučilištu u Osijeku i Sveučilištu Hacettepe u Turskoj. ${ }^{24}$ U tom istraživanju glavni je zaključak bio da su studenti većinom zadovoljni odabirom svoje profesije, no istovremeno navode i nedostatak IT-kolegija te premalo praktične nastave.

Kao što je već prije rečeno, za podizanje kvalitete studijskih programa neophodno je osluškivati mišljenja i iskustva završenih studenata. I u inozemnoj stručnoj i znanstvenoj literaturi raspravlja se o promjenama studijskih programa i kurikuluma odjela i škola koja pokrivaju područje knjižničarstva i informacijskih znanosti. Jedna od autorica koja se tim problemom bavi već dugi niz godina, Laura Saunders, provela je istraživanje kojem je cilj bio odgovoriti na pitanja koja

9. [citirano: 2019-09-20.]. Dostupno: https://www.hkdrustvo.hr/vjesnik-bibliotekara-hrvatske/ index.php/vbh/article/view/457.

19 Machala, D. Nav. dj., str. 226-227.

20 Petr Balog, K.; I. Martinović, Nav. dj., str. 15-16.

21 Petr Balog, K. Ishodi učenja Odsjeka za informacijske znanosti u Osijeku - rezultati istraživanja. // Ishodi učenja: priručnik za sveučilišne nastavnike / Lončar-Vicković, Sanja ; Dolaček-Alduk, Zlata (ur.). Osijek: Sveučilište J. J. Strossmayera, 2010. Str. 103-117. [citirano: 2019-09-22.]. Dostupno na: https://www.azoo.hr/images/Natjecanja_2014./ishodi_ucenja.pdf

22 Jozinović, T. Spremnost magistara informatologije Odsjeka za informacijske znanosti u Osijeku za tržište rada: diplomski rad. Osijek: Filozofski fakultet, 2015.

23 Isto, str. 37.

${ }^{24}$ Faletar Tanacković, S.; J. Žilić; S. Kurbanoglu; Y. Unal. Student perceptions of LIS programs and profession: Study among undergraduates in Croatia and Turkey. // The Future of Education in Information Science: Proceedings from FEIS - International EINFOSE Symposium 10-11 September 2018 Pisa, Italy / ed. by Tatjana Aparac-Jelušić, Vittore Casarosa, and Elena Macevičiūtè. Osijek: Faculty of Humanities and Social Sciences, University of Osijek, 2018. Str. 46 [citirano: 2020-10-03]. Dostupno na: http://einfose.ffos.hr/feis-2018/proceedings. 
su znanja, vještine i sposobnosti ključni za područje knjižnične i informacijske znanosti? Koja su znanja, vještine i sposobnosti važni samo praktičarima u posebnim situacijama i poslovima; prepoznaju li praktičari različite vještine kao ključne ili specijalne, ovisno o njihovu trenutnom zaposlenju, odnosno informacijskom okruženju? ${ }^{25}$ Pri izradi novih i poboljšanju postojećih studijskih programa nastavnici u Hrvatskoj susreću se s istim pitanjima. Cilj je studijskih programa pripremiti studente za široku lepezu poslova u knjižnicama, ali to podrazumijeva da studenti osim praktičnih znanja moraju dobiti i široki teorijski kontekst. Razumijevanje poslovnih procesa koji se odvijaju u suvremenoj knjižnici od studenata traži da osim praktičnih znanja razumiju širi kontekst. Saunders je provela istraživanje na 2412 ispitanika koji su završili studij akreditiran od strane Američkog knjižničarskog društva (American Library Association - ALA). ${ }^{26}$ Vrijednost tog istraživanja zanimljiva je zbog popisa 53 vještina i kompetencija koje je autorica, na temelju odgovora ispitanika, izdvojila kao ključne vještine koje bi budući knjižničari trebali usvojiti tijekom studija. Iako su rezultati istraživanja usmjereni na Sjedinjene Američke Države, mogu biti podloga za promišljanje i pomoć pri izradi novih studijskih programa ili unapređenje postojećih. Grupa autora, Bradley Wade Bishop, Adrienne W. Cadle i Tony H. Grubisic ${ }^{27}$, kao rješenje problema „prevladavanja”, odnosno prelaska mosta između ,stvarnog posla“ i onoga što se uči na studiju, vide $\mathrm{u}$ analizi poslova koji se rade po knjižnicama. Autori predlažu da se u izradu kurikuluma uključe oni koji rade u knjižnicama uz pomoć metoda koje detaljno objašnjavaju u svom članku..$^{28}$ Prije nego prijeđemo na prikaz provedenog istraživanja koje je za cilj imalo ispitati koliko studiji informacijskih znanosti/knjižničarstva u Hrvatskoj osiguravaju kompetencije za rad nakon završenog studija (najčešće u knjižnicama), potrebno je baciti pogled na ishode učenja koje studijski programi spomenutih studija navode u svojim elaboratima.

\section{Studiji informacijskih znanosti u Hrvatskoj}

U Hrvatskoj studiji informacijskih znanosti postoje na tri sveučilišta: Odjel za informacijske znanosti Sveučilišta u Zadru, Odsjek za informacijske znanosti Filozofskog fakulteta Sveučilišta Josipa Jurja Strossmayera u Osijeku, Odsjek za infor-

\footnotetext{
25 Saunders, L. Core and more: examining foundational and specialized content in library and information science. // Journal of Education for Library and Information Science 60, 1(2019), str. 8. [citirano: 2020-10-03]. Dostupno na: https://doi.org/10.3138/jelis.60.1.2018-0034

26 Na stranici http://www.ala.org/educationcareers/accreditedprograms/directory nalazi se popis programa/škola koji su akreditirali svoje programe u okviru American Library Association.

27 Bishop B.W.; A. W. Cadle; T. H. Grubisic. Job analses of emerging information professions: a survey validation of core competencies to inform curricula. // Library Quarterly Information, Community Policy 85,1(2015), str. 66. [citirano: 2020-10-03]. Dostupno na: https://doi. org/10.1086/679026.

${ }^{28}$ Autori opisuju rad s alatom DACUM - Developing a Curriculum. Isto, str. 79-81.
} 
macijske i komunikacijske znanosti Filozofskog fakulteta Sveučilišta u Zagrebu. Za potrebe razumijevanja rezultata provedenog istraživanja izdvojeni su ishodi učenja spomenutih studijskih programa na preddiplomskoj i diplomskoj razini.

\section{Odsjek za informacijske znanosti Filozofskog fakulteta Sveučilišta J. J. Strossmayera u Osijeku (u nastavku teksta Odsjek za infor- macijske znanosti u Osijeku)}

Kao što je navedeno na mrežnim stranicama Odsjeka za informacijske znanosti u Osijeku, današnji odsjek izrastao je iz Katedre za knjižničarstvo tadašnjeg Pedagoškog fakulteta u Osijeku koja je počela s radom akademske godine 1998./1999. U početku su se izvodila dva studija, redovni dodiplomski dvopredmetni studij knjižničarstva u trajanju od četiri godine i dopunski dvogodišnji izvanredni studij knjižničarstva u trajanju od dvije godine. Od 2005. g. u skladu s Bolonjskim procesom izvode se jednopredmetni preddiplomski i diplomski studiji informatologije. ${ }^{29}$

Od ak. god. 2015./2016. umjesto dosadašnjeg jednopredmetnog diplomskog studija Informatologije nudi se sljedeći dvopredmetni diplomski studiji: dvopredmetni diplomski studij Informatologije; dvopredmetni diplomski studij Informacijske tehnologije; dvopredmetni diplomski studij Nakladništva. Provedeno istraživanje uključivalo je završene studente jednopredmetnog preddiplomskog i dvopredmetnog diplomskog studija informatologije.

Ishodi učenja studijskih programa, odnosno kompetencije koje student stječe završetkom studija, sljedeće su (tablice 1. i 2.): ${ }^{30}$

Tablica 1. Preddiplomski studij Informatologije, Sveučilište u Osijeku

\begin{tabular}{|l|}
\hline Sveučilišni/a prvostupnik/prvostupnica informatologije \\
\hline identificirati i tumačiti osnovna obilježja informacijske znanosti \\
\hline opisati strukturu proizvodnje, organizacije i distribucije znanja \\
\hline $\begin{array}{l}\text { prepoznati različite vrste informacija i svojstva jedinica građe te samostalno organi- } \\
\text { zirati bibliografsko-kataložne informacije }\end{array}$ \\
\hline $\begin{array}{l}\text { opisati i analizirati složenije koncepte i kategorije deskriptivne katalogizacije i bib- } \\
\text { liografske organizacije i kontrole }\end{array}$ \\
\hline objasniti ulogu baštine i baštinskih ustanova u razvoju informacijskog društva \\
\hline
\end{tabular}

29 Povijest: Odsjek za informacijske znanosti. [citirano: 20.09.2019.] Dostupno na: https://www. ffos.unios.hr/infoznanosti/povijest

30 Odsjek za informacijske znanosti - Elaborati studijskih programa. [citirano: 2019-09-20.]. Dostupno na: https://sokrat.ffos.hr/oziz/elaborati/. 


\begin{tabular}{|l|}
\hline Sveučilišni/a prvostupnik/prvostupnica informatologije \\
\hline $\begin{array}{l}\text { definirati osnovne pojmove i koncepte u području informacijskih i baštinskih djelat- } \\
\text { nosti (informacije, baština, informacijska infrastruktura, informacijska politika itd.) } \\
\text { te upoznati temeljna obilježja knjižnično-informacijske infrastrukture u Hrvatskoj }\end{array}$ \\
\hline $\begin{array}{l}\text { definirati osnovna načela i obilježja informacijskih djelatnosti u odnosu na područje } \\
\text { bavljenja informacijske i komunikacijske znanosti }\end{array}$ \\
\hline $\begin{array}{l}\text { identificirati i tumačiti funkcije temeljnih informacijskih ustanova i njihovu ulogu u } \\
\text { suvremenom društvu, s posebnim naglaskom na pitanja profesionalne etike }\end{array}$ \\
\hline upravljati zaštitom građe u informacijskim ustanovama \\
\hline opisati temeljna načela suvremenog nakladništva i knjižarstva \\
\hline prepoznati osnovne karakteristike temeljnih nakladničkih proizvoda i žanrova \\
\hline oblikovati, upravljati i vrednovati složenije tekstualne i numeričke baze podataka \\
\hline organizirati manje digitalne zbirke i načina pretraživanja i održavanja \\
\hline izgraditi mrežna mjesta i sučelja \\
\hline pripremiti samostalno manje izdavačke projekte \\
\hline primijeniti načela i koncepte marketinga \\
\hline $\begin{array}{l}\text { analizirati utjecaj informacijske i komunikacijske tehnologije na gospodarska i } \\
\text { društvena kretanja na mikrorazini i makrorazini }\end{array}$ \\
\hline $\begin{array}{l}\text { analizirati povijesni razvoj kulture koja se zasniva na usmenom i pisanom komuni- } \\
\text { ciranju }\end{array}$ \\
\hline analizirati i kritički ocjenjivati ulogu i zadaće informacijskih stručnjaka \\
\hline $\begin{array}{l}\text { analizirati i definirati profesionalna etička načela, zakonsku regulativu i norme koje } \\
\text { se primjenjuju u struci }\end{array}$ \\
\hline analizirati, izabrati i prezentirati znanja i informacije \\
\hline $\begin{array}{l}\text { analizirati samostalno korisničku zajednicu i njezine potrebe te upravljati kn- } \\
\text { jižničnim fondom (izbor, dioba izvora, elektronički izvori i licencni ugovori, vred- } \\
\text { novanje fonda, etički aspekti itd.) }\end{array}$ \\
\hline $\begin{array}{l}\text { analizirati suvremene nakladničke trendove, kao što je internacionalizacija naklad- } \\
\text { ništva, korporativna prodaja, globalizacija i sl. }\end{array}$ \\
\hline $\begin{array}{l}\text { primijeniti vještine vrednovanja u pripremi projekata u području informacijskih } \\
\text { znanosti }\end{array}$ \\
\hline
\end{tabular}


Tablica 2. Diplomski studij Informatologije, Sveučilište u Osijeku

\begin{tabular}{|l|}
\hline Magistar/magistra informatologije \\
\hline prepoznati osnovna obilježja značajnijih razdoblja u razvoju informacijskog društva \\
\hline definirati potrebe i ponašanje korisnika informacijskih izvora \\
\hline $\begin{array}{l}\text { objasniti osnovne tehnike i metode prepoznavanja, odabiranja i zaštite jedinica pa- } \\
\text { pirne građe te načine zaštite elektroničkih dokumenata }\end{array}$ \\
\hline $\begin{array}{l}\text { opisati temeljne pristupe i postupke u izgradnji fonda i upravljanju knjižničnim } \\
\text { zbirkama (u tiskanom i elektroničkom obliku) }\end{array}$ \\
\hline definirati utjecaj osnovnih ideoloških tendencija na nakladništvo i knjižarstvo \\
\hline identificirati osnovne sastavnice uređivačkog postupka \\
\hline osmisliti i analizirati izdavački plan i dugoročnu razvojnu strategiju nakladničke kuće \\
\hline upravljati informacijama i kvalitetno ih organizirati \\
\hline kreirati, izgrađivati i vrednovati mreže i sustave za prezentaciju informacijskih izvora \\
\hline $\begin{array}{l}\text { primijeniti različite pristupe i postupke pretraživanja informacija u elektroničkom } \\
\text { okruženju }\end{array}$ \\
\hline primijeniti kriterije i metode vrednovanja različitih informacijskih izvora \\
\hline $\begin{array}{l}\text { organizirati i upravljati mrežama i sustavima u području informacijsko-komunikaci- } \\
\text { jskih tehnologija }\end{array}$ \\
\hline organizirati građu prema FRBR-modelu \\
\hline $\begin{array}{l}\text { pristupiti izradi knjižničnog kataloga u elektroničkom obliku, rabiti samostalno } \\
\text { bibliometrijske metode }\end{array}$ \\
\hline $\begin{array}{l}\text { odabrati metode i tehnike unapređivanja kvalitete te vrednovanja uspješnosti poslo- } \\
\text { vanja organizacije }\end{array}$ \\
\hline komunicirati uspješno s korisnicima i javnošću \\
\hline
\end{tabular}

\section{Odjel za informacijske znanosti Sveučilišta u Zadru (u nastavku teksta Odjel za informacijske znanosti Zadar)}

Odjel za informacijske znanosti Zadar najmlađi je studij informacijskih znanosti u Hrvatskoj. U sastavu je Sveučilišta u Zadru. Na Odjelu se izvodi nastava na preddiplomskom, diplomskom i doktorskom studiju. Diplomski studij izvodi se kao redovni i kao izvanredni studij. U dokumentu pod nazivom Odjel za infor- 
macijske znanosti: samoanaliza (2014) ${ }^{31}$ detaljno je opisana povijest Odjela - od osnutka Odjela za knjižničarstvo 2003. godine do promjene naziva 2011. u naziv Odjel za informacijske znanosti. Studijski program Odjela dostupan je na mrežnom mjestu Odjela. ${ }^{32}$

Ishodi učenja preddiplomskog i diplomskog studija informacijskih znanosti Sveučilišta u Zadru sljedeći su (tablice 3. i 4.):

Tablica 3. Preddiplomski studij Informacijske znanosti Sveučilišta u Zadru

\begin{tabular}{|l|}
\hline Prvostupnik/ica informacijskih znanosti $^{33}$ \\
\hline $\begin{array}{l}\text { prepoznati osnovna obilježja polja, njegovih grana i područja konvergencije infor- } \\
\text { macijskih i srodnih djelatnosti }\end{array}$ \\
\hline poznavati i razumjeti osnovna ishodišta i pravce razvoja kulture i civilizacije \\
\hline $\begin{array}{l}\text { prepoznati temeljne termine i koncepte u području informacijskih i komunikacijskih } \\
\text { znanosti }\end{array}$ \\
\hline razumjeti i tumačiti važnost, ciljeve i zadaće informacijskih ustanova u društvu \\
\hline $\begin{array}{l}\text { razumjeti utjecaj računala i informacijsko-komunikacijskih sustava na pojedince, } \\
\text { organizacije i društvo }\end{array}$ \\
\hline $\begin{array}{l}\text { demonstrirati stečena znanja i vještine u području izbora, organizacije, pohrane, } \\
\text { čuvanja, pretraživanja i dohvata informacija }\end{array}$ \\
\hline razumjeti i primijeniti suvremene koncepte i prakse u informacijskim tehnologijama \\
\hline $\begin{array}{l}\text { primijeniti znanja i vještine u uporabi suvremenih tehnologija i alata pri odabiru, } \\
\text { radu i/ili administriranju na računalu temeljenih informacijskih sustava (i) razumjeti } \\
\text { i primijeniti temeljna načela poslovanja informacijskih ustanova u skladu s profe- } \\
\text { sionalnim, etičkim, pravnim i sigurnosnim načelima i odgovornostima }\end{array}$ \\
\hline $\begin{array}{l}\text { primijeniti znanja i demonstrirati vještine u izgradnji i zaštiti fizičkih i digitalnih } \\
\text { zbirki građe u informacijskim ustanovama i na mreži }\end{array}$ \\
\hline $\begin{array}{l}\text { prepoznati informacijske potrebe i ponašanja ljudi i sudjelovati u oblikovanju i pro- } \\
\text { vođenju informacijskih usluga }\end{array}$ \\
\hline pomagati pri izvođenju programa informatičkog i informacijskog opismenjavanja \\
\hline
\end{tabular}

31 Odjel za informacijske znanosti: samoanaliza (2014). [citirano: 2019-09-25.]. Dostupno na: http://iz.unizd.hr/Portals/70/docs_stari_web/sa_starog_weba_ZG/SAMOANALIZA_OIZ_FIN_ potpis.pdf

32 Studijski program. [citirano: 2019-09-25.]. Dostupno na: http://iz.unizd.hr/studijski-programi.

33 Program studija. [citirano: 2019-09-25.]. Dostupno na: http://iz.unizd.hr/language/en-us/studijski-programi/preddiplomski-studij 


\section{Prvostupnik/ica informacijskih znanosti ${ }^{33}$}

primijeniti stečena znanja i vještine u radu sa sustavima i korisnicima u baštinskim ustanovama i nakladništvu u okviru njihove obrazovne, kulturne i društvene uloge

sudjelovati u pripremi informacijskih i obrazovnih materijala i pomagala $u$ informacijskim ustanovama

demonstrirati pismene i govorne komunikacijske vještine u komunikaciji s javnostima, korisnicima i pri posredovanju informacija u profesionalnoj zajednici

prepoznati problemske situacije (konkretne, virtualne i simulacije)

primijeniti društvene vještine sudjelujući u grupnom i timskom radu

sudjelovati u projektnom radu

unaprjeđivati vještine samostalnog i cjeloživotnog učenja radi daljnje formalne ili neformalne izobrazbe

Tablica 4. Diplomski studij Informacijske znanosti Sveučilišta u Zadru

\section{Magistar/magistra informacijskih znanosti (diplomski studij Informacijske znanosti, Zadar) ${ }^{34}$}

razumjeti teorijske misli i tumačiti teorijske modele te razvojne pravce i nove trendove $u$ polju informacijskih i komunikacijskih djelatnosti i znanosti

prepoznati temeljne probleme i pitanja u području informacijskih znanosti i primijeniti odgovarajuće metodološke pristupe i tehnike u njihovu istraživanju

razumjeti i tumačiti društvene $\mathrm{i}$ etičke norme i ponašanje $u$ informacijskim $\mathrm{i}$ komunikacijskim procesima

pokazati umješnost i primijeniti teorijska znanja i vještine pri izboru, organizaciji, pretraživanju, dohvatu i vrednovanju informacija te oblikovanju, održavanju, razvijanju i vrednovanju informacijskih sustava i pomagala

razumjeti i tumačiti društveno-ekonomski i kulturni kontekst u kojem djeluju informacijske ustanove i mreže i njihovu društvenu ulogu te samostalno interpretirati utjecaj računala i informacijsko-komunikacijskih sustava na pojedince, organizacije i društvo

prepoznati i tumačiti filozofijske odrednice informacije

34 Novi revidirani program Informacijske znanosti - diplomski studij. [citirano: 2019-09-25.]. Dostupno na: http://iz.unizd.hr/Portals/70/docs_stari_web/Diplomski_revidirani_program_informacijske_znanosti_2015-16_HRV.pdf 


\section{Magistar/magistra informacijskih znanosti (diplomski studij Informacijske znanosti, Zadar) ${ }^{34}$}

prepoznati i tumačiti postojeće modele i razvojne trendove $u$ istraživačkim procesima te procesima prijenosa i vrednovanja znanstvenih informacija i komunikacijskih procesa u znanosti

razumjeti i vješto primijeniti znanja i vještine u uporabi suvremenih tehnologija i alata pri odabiru, stvaranju i/ili administriranju na računalu temeljenih informacijskih sustava

razumjeti, tumačiti i primijeniti temeljna načela upravljanja informacijskim ustanovama, uključujući planiranje i izgradnju odgovarajućih fizičkih i mrežnih prostora, u skladu s profesionalnim, etičkim, pravnim i sigurnosnim načelima i odgovornostima

razumjeti i primijeniti suvremene metodološke pristupe pri istraživanjima i razvoju organizacijskih i informacijskih sustava te oblikovanju organizacije i organizacijske strukture

primijeniti znanja i demonstrirati vještine u upravljanju fizičkim i digitalnim zbirkama građe, uključujući njihovu pohranu i zaštitu, u informacijskim ustanovama i na mreži

sustavno istraživati i analizirati informacijske potrebe i ponašanja ljudi

prepoznavati važnost, istraživati probleme i pokretati procese oblikovanja i provođenja novih oblika informacijskih usluga

odabirati, vrednovati, primijeniti i upravljati informacijskim i računalnim sustavima u baštinskim ustanovama i nakladništvu u okviru njihove obrazovne, kulturne i društvene uloge

demonstrirati inovativnost u dizajniranju informacijskih i obrazovnih materijala i pomagala

demonstrirati visoku razinu pismene i govorne komunikacijske vještine u komunikaciji s javnošću, korisnicima i pri posredovanju informacija u profesionalnoj zajednici

prepoznati probleme u upravljanju informacijskim ustanovama, sustavima i mrežama (konkretne, virtualne i simulacije) te ponuditi mogućnosti za njihovo rješavanje

znalački primijeniti društvene vještine u grupnom i timskom radu

prepoznati i rješavati probleme u sklopu pilot-projekata

sustavno unaprjeđivati vještine samostalnog i cjeloživotnog učenja 


\section{Odsjek za informacijske i komunikacijske znanosti Filozofskog fa- kulteta Sveučilišta u Zagrebu (u nastavku teksta Odsjek za infor- macijske i komunikacijske znanosti, Zagreb) ${ }^{35}$}

Odsjek za informacijske i komunikacijske znanosti, Zagreb najstariji je u Hrvatskoj. U Povijesti nastanka Odsjeka ${ }^{36}$ navodi se 1981. godina kao ključna za osnivanje Odsjeka jer su se dvije katedre, Katedra za bibliotekarstvo i Katedra za društveno-humanističku informatiku, spojile. Odsjek za informacijske znanosti nastaje 1984. godine osnivanjem Katedri za arhivistiku i muzeologiju uz već postojeće Katedre za bibliotekarstvo i Katedre za društveno-humanističku informatiku. U opisu rada Katedre za bibliotekarstva danas navodi se da „nastavnici sa Katedre izvode nastavu na svim razinama studija s naglaskom na obvezne

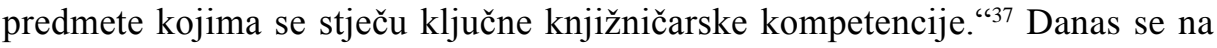
studiju može studirati preddiplomski, diplomski i doktorski studij. Kao i u Zadru, moguće je upisati i izvanredni studij. ${ }^{38}$ Moguće je upisati jednopredmetni ili dvopredmetni studij, a na tim razinama razlikuju se i ishodi učenja (tablice 5. i 6.).

Tablica 5. Preddiplomski studij Informacijskih znanosti - jednopredmetni

\section{Sveučilišni prvostupnik/prvostupnica informacijskih znanosti ${ }^{39}$ - jednopred- metni studij}

identificirati i usporediti vodeće trendove i razvoj računalnih tehnologija te tehnologije naprednog pretraživanja

demonstrirati vještine stručne usmene i pismene komunikacije

interpretirati probleme vezane uz dizajn, razvoj, evaluaciju i realizaciju dijaloških sustava utemeljenih na prirodnom jeziku

interpretirati i riješiti informacijske potrebe korisnika

\footnotetext{
35 Odjel za informacijske znanosti. [citirano: 2019-09-25.]. Dostupno na: https://inf.ffzg.unizg. hr/index.php/hr/

36 Povijest nastanka Odsjeka. [citirano: 2019-09-25.]. Dostupno na: https://inf.ffzg.unizg.hr/index.php/hr/odsjek/povijest-nastanka-odsjeka

37 Odsjek za informacijske i komunikacijske znanosti Filozofskog fakulteta Sveučilišta u Zagrebu. / uredila Jadranka Lasić-Lazić. Zagreb: Zavod za informacijske studije, 2013. Str. 44.

38 ECTS Informacijski paket za akademsku godinu 2019./2020.: Informacijske znanosti, diplomski. [citirano: 2019-09-25.]. Dostupno na: http://theta.ffzg.hr/ECTS/Studij/Index/4447

39 ECTS Informacijski paket za akademsku godinu 2019./2020.: Informacijske znanosti, preddiplomski. [citirano: 2019-09-25.]. Dostupno na: http://theta.ffzg.hr/ECTS/Studij/Index/928
} 


\begin{tabular}{|l|}
\hline $\begin{array}{l}\text { Sveučilišni prvostupnik/prvostupnica informacijskih znanosti } \\
\text { metni studij }\end{array}$ \\
\hline $\begin{array}{l}\text { odabrati i upotrijebiti informatičke, informacijske i logičke modele u informaci- } \\
\text { jskim i komunikacijskim znanostima }\end{array}$ \\
\hline $\begin{array}{l}\text { demonstrirati poznavanje osnovnih aktivnosti upravljanja zbirkama predmeta baš- } \\
\text { tine i informacija o njima }\end{array}$ \\
\hline interpretirati i rabiti stručnu terminologiju na hrvatskom i engleskom jeziku \\
\hline $\begin{array}{l}\text { primijeniti i izgraditi baze podataka i sustave za pretraživanje informacija u infor- } \\
\text { macijskom sustavu }\end{array}$ \\
\hline primijeniti postupke i načela obrade multimedijskih elemenata \\
\hline pronaći, vrednovati i primijeniti informacije i/ili informacijske izvore \\
\hline sudjelovati na projektima iz područja informacijskih i komunikacijskih znanosti \\
\hline $\begin{array}{l}\text { odabrati i upotrijebiti metode i tehnike obrade i organizacije dokumenata u fizičkim } \\
\text { i digitalnim zbirkama i fondovima }\end{array}$ \\
\hline prikazati funkcioniranje informacijskih institucija \\
\hline prepoznati, opisati i povezati informacijske službe, sustave i usluge \\
\hline $\begin{array}{l}\text { primijeniti, kritički procijeniti i povezati znanja iz upravljanja složenim informaci- } \\
\text { jskim sustavima }\end{array}$ \\
\hline primijeniti i integrirati znanja i algoritme u izradi programskih rješenja \\
\hline $\begin{array}{l}\text { upotrijebiti funkcije zaštite, istraživanja i komunikacije u informacijskim ustanova- } \\
\text { ma i izvan njih }\end{array}$ \\
\hline $\begin{array}{l}\text { prepoznati i primijeniti rezultate istraživanja iz polja informacijskih i komunikaci- } \\
\text { jskih znanosti }\end{array}$ \\
\hline provoditi i ocijeniti programe zaštitite građe i podataka \\
\hline $\begin{array}{l}\text { primijeniti spoznaje teorijjkih i metodoloških znanja informacijskih i komunikaci- } \\
\text { jskih znanosti u rješavanju problema na stručnoj razini }\end{array}$ \\
\hline vrednovati i odabrati najprikladnija informacijska rješenja za zahtjeve struke \\
\hline primijeniti znanja iz različitih područja računalne obrade jezika \\
\hline
\end{tabular}


Tablica 6. Preddiplomski studij Informacijskih znanosti - dvopredmetni

\begin{tabular}{|l|}
\hline $\begin{array}{l}\text { Sveučilišni prvostupnik/prvostupnica informacijskih znanosti - dvopredmetni } \\
\text { preddiplomski studij }\end{array}$ \\
\hline identificirati informacijske potrebe korisnika \\
\hline nabrojati i opisati postupke i načela obrade multimedijskih elemenata \\
\hline demonstrirati vještine stručne usmene i pismene komunikacije \\
\hline $\begin{array}{l}\text { prepoznati, razlikovati i rabiti metode i tehnike obrade i organizacije dokumenata u } \\
\text { fizičkim i digitalnim zbirkama i fondovima }\end{array}$ \\
\hline $\begin{array}{l}\text { prepoznati i primijeniti rezultate istraživanja iz polja informacijskih i komunikaci- } \\
\text { jskih znanosti }\end{array}$ \\
\hline interpretirati i rabiti stručnu terminologiju na hrvatskom i engleskom jeziku \\
\hline razumjeti i opisati funkcioniranje informacijskih institucija \\
\hline vrednovati i odabrati najprikladnija informacijska rješenja za zahtjeve struke \\
\hline $\begin{array}{l}\text { primijeniti baze podataka i sustave za pretraživanje informacija u informacijskom } \\
\text { sustavu }\end{array}$ \\
\hline $\begin{array}{l}\text { odabrati i prikazati vodeće trendove i razvoj računalnih tehnologija te tehnologije } \\
\text { naprednog pretraživanja }\end{array}$ \\
\hline $\begin{array}{l}\text { razumjeti i opisati funkcije zaštite, istraživanja i komunikacije u informacijskim } \\
\text { ustanovama i izvan njih }\end{array}$ \\
\hline $\begin{array}{l}\text { prepoznati i klasificirati probleme vezane uz dizajn, razvoj, evaluaciju i realizaciju } \\
\text { dijaloških sustava utemeljenih na prirodnom jeziku }\end{array}$ \\
\hline $\begin{array}{l}\text { opisati i reproducirati informatičke, informacijske i logičke modele u informaci- } \\
\text { jskim i komunikacijskim znanostima }\end{array}$ \\
\hline provoditi programe zaštitite građe i podataka \\
\hline $\begin{array}{l}\text { opisati poznavanje osnovnih aktivnosti upravljanja zbirkama predmeta baštine i } \\
\text { informacija o njima }\end{array}$ \\
\hline primijeniti spoznaje teorijskih i metodoloških znanja informacijskih i komunikaci- \\
jskih znanosti u rješavanju problema na stručnoj razini \\
\hline primijeniti znanja iz različitih područja računalne obrade jezika \\
\hline primijeniti znanja iz upravljanja složenim informacijskim sustavima \\
\hline sudjelovati na projektima iz područja informacijskih i komunikacijskih znanosti \\
\hline primijeniti znanja i algoritme u izradi programskih rješenja \\
\hline identificirati, klasificirati i vrednovati informacije i/ili informacijske izvore \\
\hline prepoznati i opisati informacijske službe, sustave i usluge \\
\hline
\end{tabular}


Na diplomskom studiju studenti se mogu odlučiti za smjer Bibliotekarstvo. Nakon završetka studija student dobiva titulu magistar/magistra bibliotekarstva. Na jednopredmetnom studiju ishodi su učenja (tablica 7.): ${ }^{40}$

Tablica 7. Diplomski studij Bibliotekarstvo - jednopredmetni

\begin{tabular}{|l|}
\hline Magistar/magistra bibliotekarstva - jednopredmetni studij \\
\hline analizirati, prikazivati i tumačiti informacije \\
\hline kvantitativno i kvalitativno vrednovati službe i usluge \\
\hline interpretirati odnose među proizvođačem, posrednikom i korisnikom informacija \\
\hline $\begin{array}{l}\text { rabiti nacionalne i međunarodne pravne i administrativne propise koji se odnose na } \\
\text { nastanak, prijenos i uporabu informacija }\end{array}$ \\
\hline identificirati i vrednovati informacije i/ili informacijske izvore \\
\hline $\begin{array}{l}\text { identificirati i analizirati način na koji informacije nastaju, kolaju i rabe se, razvijati } \\
\text { usluge i programe za korisnike }\end{array}$ \\
\hline planirati i voditi stručne projekte \\
\hline upravljati analognim i digitalnim zbirkama i fondovima \\
\hline organizirati, označavati i pretraživati informacije i/ili informacijske izvore \\
\hline procjenjivati informacijske potrebe i planirati odgovarajuće službe i usluge \\
\hline provoditi programe zaštitite građe i podataka \\
\hline $\begin{array}{l}\text { tumačiti povijesni razvoj informacijske struke i preispitivati mogućnosti njezina } \\
\text { budućeg razvoja }\end{array}$ \\
\hline provoditi marketinške postupke u svrhu komunikacije s javnošću \\
\hline
\end{tabular}

Na dvopredmetnom studiju Bibliotekarstva ishodi su učenja (tablica 8.):

Tablica 8. Diplomski studij Bibliotekarstvo - dvopredmetni

\begin{tabular}{|l|}
\hline Magistar/magistra bibliotekarstva - dvopredmetni studij ${ }^{41}$ \\
\hline identificirati i analizirati način na koji informacije nastaju, kolaju i rabe se \\
\hline analizirati, prikazivati i tumačiti informacije \\
\hline identificirati i vrednovati informacije i/ili informacijske izvore \\
\hline
\end{tabular}

40 ECTS Informacijski paket za akademsku godinu 2019./2020.: Informacijske znanosti, smjer Bibliotekarstvo, jednopredmetni. [citirano: 2019-09-25.]. Dostupno na: http://theta.ffzg.hr/ECTS/ Studij/Index/1170

${ }^{41}$ ECTS Informacijski paket za akademsku godinu 2019./2020.: Informacijske znanosti, smjer Bibliotekarstvo, dvopredmetni. [citirano: 2019-09-25.]. Dostupno na: http://theta.ffzg.hr/ECTS/ Studij/Index/1175 


\begin{tabular}{|l|}
\hline Magistar/magistra bibliotekarstva - dvopredmetni studij ${ }^{41}$ \\
\hline interpretirati odnose među proizvođačem, posrednikom i korisnikom informacija \\
\hline $\begin{array}{l}\text { rabiti nacionalne i međunarodne pravne i administrativne propise koji se odnose na } \\
\text { nastanak, prijenos i uporabu informacija }\end{array}$ \\
\hline $\begin{array}{l}\text { tumačiti povijesni razvoj informacijske struke i preispitivati mogućnosti njezina } \\
\text { budućeg razvoja }\end{array}$ \\
\hline kvantitativno i kvalitativno vrednovati službe i usluge \\
\hline provoditi programe zaštitite građe i podataka \\
\hline organizirati, označavati i pretraživati informacije i/ili informacijske izvore \\
\hline razvijati usluge i programe za korisnike \\
\hline planirati i voditi stručne projekte \\
\hline upravljati analognim i digitalnim zbirkama i fondovima \\
\hline procjenjivati informacijske potrebe i planirati odgovarajuće službe i usluge \\
\hline provoditi marketinške postupke u svrhu komunikacije s javnošću \\
\hline
\end{tabular}

Bez obzira na razlike u zvanjima, na sva tri odjela/odsjeka ishodi učenja na preddiplomskoj razini pokrivaju šire polje informacijskih znanosti. Na diplomskom studiju ishodi učenja usmjereni su prema knjižničarstvu. No treba naglasiti kako je takva situacija barem djelomično pod utjecajem postojanja Pravilnika o uvjetima i načinu stjecanja stručnih zvanja u knjižničarskoj struci ${ }^{42}$ koji definira zapošljavanje knjižničara te studiji moraju zadovoljiti postojeće zahtjeve.

\section{Istraživanje}

Cilj provedenog istraživanja bio je ispitati:

1. u kojoj mjeri preddiplomski i diplomski studiji informacijskih znanosti na sveučilištima u Zagrebu, Osijeku i Zadru pripremaju studente za buduće poslove u knjižnicama, odnosno

2. u kojoj mjeri studijski programi studija informacijskih znanosti na sveučilištima u Zagrebu, Osijeku i Zadru iz perspektive bivših studenata osiguravaju potrebne kompetencije.

To su ujedno i glavna istraživačka pitanja, a pretpostavka od koje se krenulo jest da studiji osiguravaju kompetencije potrebne za knjižničarske poslove, odnosno da ispitanici percipiraju kompetencije koje su dobili na studiju kao odgovara-

42 Pravilnik o uvjetima i načinu stjecanja stručnih zvanja u knjižničarskoj struci (NN 28/11, NN 16/14, NN 60/14 - ispravak, NN 47/17). 
juće za posao koji obavljaju. Za potrebe istraživanja pripremljen je mrežni anketni upitnik podijeljen u sljedeće grupe pitanja: sociodemografski podaci; motivi upisa na studij informacijskih znanosti/knjižničarstva; podaci o zaposlenju; procjena kompetencija stečenih na studiju; alumni-mreža; studentska praksa; članstvo i aktivnost u stručnim udruženjima.

\section{Uzorak}

Upitnik je distribuiran alumni-klubovima koji su zamoljeni da proslijede upitnik svojim članovima, odnosno putem osobnih poznanstava autora s bivšim studentima. Kontaktirane osobe zamoljene su da pošalju upitnik svim svojim poznanicima koji su završili studiji informatologije ili knjižničarstva unazad deset godina, što je u konačnici rezultiralo nereprezentativnim prigodnim uzorkom. Upitnik je tijekom rujna i listopada 2018. godine ispunilo 122 ispitanika sljedećih karakteristika (tablica 1.):

Tablica 9. Sociodemografska obilježja

\begin{tabular}{|c|c|c|}
\hline Spol $(\mathrm{N}=122)$ & $\mathrm{n}$ & $\%$ \\
\hline Ženski & 103 & 84,4 \\
\hline Muški & 18 & 14,8 \\
\hline Bez odgovora & 1 & 8 \\
\hline $\operatorname{Dob}(\mathrm{N}=122)$ & $\mathbf{n}$ & $\%$ \\
\hline do 30 & 52 & 42,6 \\
\hline $31-40$ & 49 & 40,2 \\
\hline $41-50$ & 13 & 10,7 \\
\hline 50 i više & 8 & 6,6 \\
\hline Mjesto rada $(\mathrm{N}=122)$ & $\mathbf{n}$ & $\%$ \\
\hline Zagreb i okolica & 37 & 30,3 \\
\hline Osijek i okolica & 13 & 10,7 \\
\hline Zadar i okolica & 40 & 32,8 \\
\hline Ostalo & 24 & 19,7 \\
\hline Bez odgovora & 8 & 6,6 \\
\hline
\end{tabular}




\begin{tabular}{|l|r|r|}
\hline Vrsta završenog studija $(\mathrm{N}=122)$ & $\mathbf{n}$ & $\mathbf{\%}$ \\
\hline Redoviti & 68 & 55,7 \\
\hline Izvanredni & 52 & 42,6 \\
\hline Bez odgovora & 2 & 1,6 \\
\hline & & \\
Jeste li zaposleni? $(\mathrm{N}=122)$ & $\mathrm{n}$ & $\%$ \\
\hline Da, za stalno & 78 & 63,9 \\
\hline Da, ne za stalno & 31 & 25,4 \\
\hline Nisam zaposlen/a & 13 & 10,7 \\
\hline & & \\
Gdje radite (N = 109) & $\mathrm{n}$ & $\%$ \\
\hline U knjižnici & 80 & 73,4 \\
\hline U drugoj informacijskoj ustanovi & 3 & 2,7 \\
\hline Negdje drugdje & 26 & 23,9 \\
\hline
\end{tabular}

U pogledu geografske zastupljenosti ispitanici su okupljeni oko 3 grada u kojima postoje studiji informacijskih znanosti. Okolica je u ovom radu definirana kao područje gravitiranja gradova u okrugu od $100 \mathrm{~km}$ zračne linije, a mjesta koja su izvan tog okruga svrstana su pod ostalo. Iz raspodjele u uzorku vidimo da je dobivena lagana nadzastupljenost ženskog spola i zadarske regije, no odstupanja od predviđene reprezentativnosti u okvirima su prihvatljivoga za ovu vrstu istraživanja. Dodatno treba naglasiti da je raspodjela po godinama završetka relativno ravnomjerna u rasponu od 2009. do 2018. godine, što znači da su svi ispitanici završili studij unutar predviđenih deset godina od dana ispunjavanja upitnika. $89,3 \%$ ispitanika zaposleno je, od čega $73,4 \%$ radi u knjižnici s prosječnim radnim stažem u knjižničarstvu od 7,8 godina.

\section{Razlozi studiranja}

U prvom dijelu upitnika ispitanicima je ponuđen niz tvrdnji kojima se željelo ispitati razloge zbog kojih su se odlučili za studij knjižničarstva ili informacijskih znanosti (tablica 10.). Uz svaku tvrdnju ponuđena je petstupanjska skala Likertova tipa (1. Uopće se ne slažem, 2. Djelomično se ne slažem, 3. Niti se slažem niti ne slažem, 4. Djelomično se slažem, 5. U potpunosti se slažem). U tablici su prikaza- 
ne srednje vrijednosti odgovora ispitanika (AS - aritmetička sredina). Dodatno su navedene razlike između ispitanika koji su studirali izvanredni, odnosno redoviti studij. Kako distribucije rezultata po česticama nisu zadovoljavale kriterij normalnosti za testiranje razlike, uporabljen je Mann-Whitneyev neparametrijski test, a granica statističke značajnosti postavljena je na standardnoj razini $\mathrm{p}<0.05$.

Tablica 10. Razlozi studiranja

\begin{tabular}{|l|r|r|c|c|}
\hline \multirow{2}{*}{$\begin{array}{l}\text { Zašto ste se odlučili za studij knjižničarstva/ } \\
\text { informacijskih znanosti? }\end{array}$} & & \multicolumn{2}{|c|}{ Srednji rang } & \\
\cline { 2 - 5 } & AS & Red. & Izv. & p \\
\hline $\begin{array}{l}\text { Želio/la sam studirati knjižničarstvo/ } \\
\text { informacijske znanosti }\end{array}$ & 4,09 & 56,9 & 57,1 & 0,982 \\
\hline Želio/la sam raditi u knjižnici & 4,18 & 52,3 & 64,7 & 0,027 \\
\hline $\begin{array}{l}\text { Radio/la sam u knjižnici, ali nisam imao/la } \\
\text { odgovarajuću stručnu spremu }\end{array}$ & 2,53 & 35,6 & 89,3 & 0,000 \\
\hline Očekivao/la sam radno mjesto u knjižnici & 2,66 & 51,5 & 64,7 & 0,025 \\
\hline $\begin{array}{l}\text { Mislio/la sam da ću se lako zaposliti u knjižni- } \\
\text { ci/informacijskoj ustanovi }\end{array}$ & 2,75 & 61,6 & 50,6 & 0,067 \\
\hline Zanimalo me područje informacijskih znanosti & 3,97 & 56,1 & 57,1 & 0,870 \\
\hline $\begin{array}{l}\text { Moji prijatelji studirali su na istoj grupi pa sam } \\
\text { došao/la i ja }\end{array}$ & 1,30 & 55,5 & 56,8 & 0,707 \\
\hline $\begin{array}{l}\text { Nisam znao/la koju grupu odabrati pa sam } \\
\text { se upisao/la na knjižničarstvo/informacijske } \\
\text { znanosti }\end{array}$ & 1,50 & 63,8 & 48,5 & 0,001 \\
\hline Želio/la sam drugu grupu, ali nisam upisao/la & 1,59 & 63,6 & 47,7 & 0,000 \\
\hline Čuo/la sam kako je to lagano studirati & 1,31 & 60,9 & 51,5 & 0,014 \\
\hline $\begin{array}{l}\text { Mislio/la sam kako je to perspektivno područje } \\
\text { i da ću lako pronaći posao }\end{array}$ & 2,96 & 69,9 & 38,9 & 0,000 \\
\hline
\end{tabular}

Iz rezultata prikazanih u tablici možemo zaključiti kako razlozi studiranja uglavnom nisu oportunističke prirode. Ispitanici u velikoj mjeri iskazuju stav kako su željeli studirati knjižničarstvo/informacijske znanosti, odnosno da ih je zanimalo to područje, a vrlo malo ispitanika iskazuje razloge poput laganog studiranja, nemogućnosti upisivanja nečeg drugog, nisam znao/la što bih drugo i slično. Očekivano, kod izvanrednih studenata češći je razlog upisivanja studija postojeći posao u knjižnici. Potrebno je istaknuti i kako redoviti studenti u puno većoj mjeri kao razlog izbora studija navode perspektivnost područja. 
Kao što je istaknuto u uvodu članka, pri izradi studijskih programa nastavnici se vode i pitanjem koje su to vještine i znanja potrebni studentima da se što brže i jednostavnije uklope na tržište rada nakon završenog školovanja. Stoga je u sljedećem bloku pitanja ispitanicima ponuđeno da procijene u kojoj mjeri smatraju da su na studiju dobili knjižničarske, odnosno opće kompetencije.

\section{Zadovoljstvo radnim mjestom i ocjena stečenih znanja i vještina}

Kao uvod u sljedeći niz postavljena su dva uvodna pitanja o općem zadovoljstvu radnim mjestom (postavljeno svim ispitanicima) i pitanje o općenitoj korisnosti na studiju stečenih znanja i vještina.

Tablica 11. Zadovoljstvo radnim mjestom i ocjena stečenih znanja i vještina

\begin{tabular}{|l|c|c|c|c|}
\hline \multirow{2}{*}{} & & \multicolumn{2}{|c|}{ Srednji rang } & \\
\cline { 2 - 5 } & AS & Red. & Izv. & p \\
\hline $\begin{array}{l}\text { U kojoj ste mjeri zadovoljni svojim radnim } \\
\text { mjestom? * }\end{array}$ & 4,21 & 49,7 & 64,6 & 0,008 \\
\hline $\begin{array}{l}\text { U kojoj su Vam mjeri znanja i vještine stečene } \\
\text { na studiju korisne pri radu u knjižnici? ** }\end{array}$ & 3,79 & 35,0 & 43,6 & 0,054 \\
\hline
\end{tabular}

* Skala: 1. U potpunosti nezadovoljan/a, 2. Djelomično nezadovoljan/a, 3. Niti zadovoljan/a niti nezadovoljan/a, 4. Djelomično zadovoljan/a, 5. Potpuno zadovoljan/a

** Skala: 1. Uopće nisu korisne, 2. Uglavnom nisu korisne, 3. Niti jesu niti nisu korisne, 4. Uglavnom jesu korisne, 5. U potpunosti su korisne

Kako je vidljivo u tablici 11., opće zadovoljstvo radnim mjestom prilično je visoko $(4,21)$ i veće je kod izvanrednih studenata nego kod redovitih. Kako je to pitanje postavljeno svim ispitanicima, činilo se da bi razlika mogla zapravo biti između onih ispitanika koji rade i koji ne rade u knjižnici jer veći broj izvanrednih studenata radi u knjižnici od redovitih (78,8 \% izvanrednih u odnosu na 54,4\% redovitih, $\left.\chi^{2}=7,733, \mathrm{p}=0,005\right)$, no pokazalo se kako između onih koji rade i koji ne rade u knjižnici nema značajne razlike u zadovoljstvu radnim mjestom $(\mathrm{U}=1131,5$, $\mathrm{p}=0,092)$.

Kad je u pitanju opća procjena korisnosti znanja i vještina stečenih na studiju pri radu u knjižnici, ocjena je korisnosti nešto niža $(3,79)$, a s obzirom na skalu korisnosti od 1 do 5 možemo reći kako rezultat nije visok. S obzirom na to da se to pitanje odnosilo na korisnost znanja i vještina za rad u knjižnici, ono je postavljeno samo ispitanicima koji rade u knjižnici. 


\section{Procjena stečenih kompetencija}

U tablicama 12. i 13. prikazane su procjene ispitanika u kojoj su mjeri na studiju dobili knjižničarske kompetencije (tablica 12.) i opće kompetencije (tablica 13.). U oba instrumenta uporabljena je petstupanjska skala Likertova tipa (1. Uopće nisam dobio/la, 2. Uglavnom nisam dobio/la, 3. Niti jesam niti nisam dobio/la, 4. Uglavnom jesam dobio/la, 5. U potpunosti sam dobio/la).

U instrumentu je uporabljen popis općih i knjižničarskih kompetencija koje je Dijana Machala rabila u istraživanju 2009. i 2011. godine pod nazivom „Ispitna pitanja o važnosti i usvojenosti područnospecifičnih i generičkih kompetencija novodiplomiranih knjižničara nakon završetka studija knjižničarstva“". ${ }^{43}$

Tablica 12. Procjena stečenih knjižničarskih kompetencija

\begin{tabular}{|l|c|c|c|c|}
\hline \multirow{2}{*}{$\begin{array}{l}\text { Molimo, procijenite u kojoj ste mjeri na studiju } \\
\text { dobili sljedeće knjižničarske kompetencije. }\end{array}$} & \multicolumn{3}{|c|}{$\begin{array}{c}\text { Srednji } \\
\text { rang }\end{array}$} & \\
\cline { 2 - 5 } & AS & Red. & Izv. & p \\
\hline Vještine pretraživanja i vrednovanja informacija & 4,10 & 44,6 & 34,9 & 0,044 \\
\hline $\begin{array}{l}\text { Učinkovito pružanje informacija za potrebe ko- } \\
\text { risnika }\end{array}$ & 3,92 & 44,3 & 34,1 & 0,035 \\
\hline Vještine uporabe informacijskih pomagala i izvora & 3,92 & 42,7 & 35,6 & 0,140 \\
\hline Sposobnost pružanja i razvijanja usluga za korisnike & 3,67 & 39,5 & 38,6 & 0,850 \\
\hline Znanje i primjena izgradnje i upravljanja zbirkama & 3,75 & 37,6 & 40,3 & 0,564 \\
\hline $\begin{array}{l}\text { Znanje i primjena izgradnje i upravljanja digitalnim } \\
\text { zbirkama }\end{array}$ & 3,22 & 37,9 & 39,1 & 0,804 \\
\hline Znanje i sposobnost sadržajne obrade građe & 3,66 & 39,4 & 38,7 & 0,886 \\
\hline Razumijevanje zakonskih i etičkih okvira & 3,55 & 37,5 & 39,5 & 0,684 \\
\hline Znanje i sposobnost formalne obrade građe & 3,92 & 41,7 & 35,7 & 0,202 \\
\hline $\begin{array}{l}\text { Sposobnost upravljanja i uporabe informacijskih } \\
\text { tehnologija }\end{array}$ & 3,79 & 43,6 & 33,1 & 0,027 \\
\hline $\begin{array}{l}\text { Vještine i sposobnost javnog komuniciranja i djelo- } \\
\text { vanja }\end{array}$ & 3,41 & 39,7 & 38,4 & 0,796 \\
\hline Sposobnost poučavanja korisnika & 3,32 & 36,8 & 39,1 & 0,645 \\
\hline
\end{tabular}

43 Machala, D. Nav. dj., str. 215-222. 


\begin{tabular}{|c|c|c|c|c|}
\hline \multirow{2}{*}{$\begin{array}{l}\text { Molimo, procijenite u kojoj ste mjeri na studiju } \\
\text { dobili sljedeće knjižničarske kompetencije. }\end{array}$} & \multicolumn{3}{|c|}{$\begin{array}{l}\text { Srednji } \\
\text { rang }\end{array}$} & \multirow[b]{2}{*}{$\mathbf{p}$} \\
\hline & AS & Red. & Izv. & \\
\hline $\begin{array}{l}\text { Upravljanje procesima informatizacije knjižničnog } \\
\text { poslovanja (OPAC, knjižnični sustav) }\end{array}$ & 3,28 & 38,9 & 39,1 & 0,953 \\
\hline Znanje i primjena istraživačkih metoda & 3,53 & 38,9 & 39,1 & 0,966 \\
\hline Znanje i primjena postupaka zaštite i pohrane građe & 3,60 & 38,9 & 38,1 & 0,857 \\
\hline Znanje i primjena temeljnih teorijskih načela & 3,97 & 42,7 & 35,6 & 0,125 \\
\hline Znanja i vještine upravljanja procesima digitalizacije & 3,19 & 45,3 & 33,2 & 0,014 \\
\hline Znanje i sposobnost kreiranja novog znanja & 3,35 & 37,8 & 38,2 & 0,942 \\
\hline Znanje pedagogije i metodike poučavanja & 2,61 & 35,5 & 42,3 & 0,170 \\
\hline $\begin{array}{l}\text { Sposobnost organizacije i izvođenja programa iz } \\
\text { kulture }\end{array}$ & 2,78 & 35,8 & 42,0 & 0,214 \\
\hline Znanje i razumijevanje izdavačkog procesa & 3,15 & 41,8 & 36,4 & 0,270 \\
\hline
\end{tabular}

Rezultati pokazuju kako jedino kod vještine pretraživanja i vrednovanja informacija prosječna ocjena prelazi 4. Općenito možemo reći kako su najbolje ocijenjene kompetencije koje predstavljaju klasičnu knjižničarsku jezgru (poput Vještine pretraživanja i vrednovanja informacija $(4,10)$ i drugih), dok su one koje uključuju digitalne kompetencije u pravilu slabije ocijenjene, poput Znanja $i$ vještina upravljanja procesima digitalizacije $(3,19)$ ili Informatizacije knjižničnog poslovanja $(3,28)$, koje su vrlo blizu neutralnoj opciji Niti jesam niti nisam dobio/la.

Slična je situacija i s procjenom dobivenih općih kompetencije (tablica 13.). Najbolje su ocijenjene Vještine prikupljanja $i$ upravljanja informacijama $(4,02)$ i Vještine uporabe računala $(3,99)$, a najslabije (ako zanemarimo znanje stranog jezika) Sposobnost primjene teorijskog znanja u praksi $(3,54)$.

Tablica 13. Procjena stečenih općih kompetencija

\begin{tabular}{|l|c|c|c|c|}
\hline \multirow{2}{*}{$\begin{array}{l}\text { Molimo, procijenite u kojoj ste mjeri na studi- } \\
\text { ju dobili sljedeće opće kompetencije. }\end{array}$} & & \multicolumn{2}{|c|}{ Srednji rang } & \\
\cline { 2 - 5 } & AS & Red. & Izv. & p \\
\hline Osnovne vještine uporabe računala & 3,99 & 70,6 & 45,9 & $0,000^{*}$ \\
\hline Vještine prikupljanja i upravljanja informacijama & 4,02 & 65,8 & 53,6 & $0,043^{*}$ \\
\hline Sposobnosti za timski rad & 3,71 & 69,1 & 47,8 & $0,001^{*}$ \\
\hline
\end{tabular}




\begin{tabular}{|c|c|c|c|c|}
\hline \multirow{2}{*}{$\begin{array}{l}\text { Molimo, procijenite u kojoj ste mjeri na studi- } \\
\text { ju dobili sljedeće opće kompetencije. }\end{array}$} & \multirow[b]{2}{*}{ AS } & \multicolumn{2}{|c|}{ Srednji rang } & \multirow[b]{2}{*}{$\mathbf{p}$} \\
\hline & & Red. & Izv. & \\
\hline Etičnost & 3,93 & 65,2 & 53,1 & $0,045^{*}$ \\
\hline Komunikacijske vještine & 3,62 & 66,2 & 51,8 & $0,019^{*}$ \\
\hline Sposobnost primjene teorijskog znanja u praksi & 3,54 & 59,7 & 59,3 & 0,951 \\
\hline Samostalnost u radu & 3,93 & 64,9 & 53,4 & 0,058 \\
\hline Sposobnost prilagodbe novim situacijama & 3,74 & 66,4 & 51,5 & $0,015^{*}$ \\
\hline Organizacijske sposobnost i vještine upravljanja & 3,62 & 62,3 & 57,0 & 0,388 \\
\hline Kritičke i samokritičke sposobnosti & 3,64 & 63,2 & 55,8 & 0,229 \\
\hline Znanje stranog jezika & 2,93 & 65,0 & 52,0 & $0,036^{*}$ \\
\hline Istraživačke metode, stručni i znanstveni rad & 3,80 & 61,6 & 57,9 & 0,552 \\
\hline Želja za uspjehom & 3,69 & 63,2 & 55,7 & 0,220 \\
\hline
\end{tabular}

Na svim česticama oba instrumenta napravljena je i usporedba između redovitih i izvanrednih studenata, no značajnih je razlika vrlo malo, pogotovo kod knjižničarskih kompetencija. Međutim na svim česticama gdje se pokazuju statistički značajne razlike (označene zvjezdicom u tablici 13.), redoviti studenti bolje ocjenjuju razinu dobivenih specifičnih kompetencija. Može se pretpostaviti da karakter redovitog studija, barem kod pojedinih specifičnih kompetencija, doprinosi boljem krajnjem rezultatu.

\section{Praktična nastava i opće zadovoljstvo}

Jedan od važnih segmenata studija jest i praktična nastava u informacijskim ustanovama, uglavnom knjižnicama. Ispitanicima je dano da procijene koliko su imali praktične nastave tijekom studija petstupanjskom skalom Likertova tipa (1. Potpuno nedovoljno, 2. Uglavnom nedovoljno, 3. Niti dovoljno niti nedovoljno, 4. Uglavnom dovoljno, 5. Potpuno dovoljno). U tablici 14. vidimo da se prosječan odgovor ispitanika nalazi u negativnom dijelu skale $(2,7)$, što znači da veći broj ispitanika ocjenjuje kako nije bilo dovoljno prakse tijekom studija. Pogotovo je to izraženo kod izvanrednih studenata koji količinu prakse ocjenjuju negativnije od redovitih studenata. Tu ipak treba naglasiti kako je većina izvanrednih studenata $u$ radnom odnosu, zbog čega organizacija prakse izvanrednih studenata predstavlja velik izazov prilikom organizacije studija, što u konačnici rezultira manjom količinom praktične nastave. 
Tablica 14. Praksa na studiju

\begin{tabular}{|l|c|c|c|c|}
\hline \multirow{2}{*}{} & & \multicolumn{2}{|c|}{ Srednji rang } & \\
\cline { 2 - 5 } & AS & Red. & Izv. & p \\
\hline $\begin{array}{l}\text { Procijenite koliko je na studiju koji ste završi- } \\
\text { li bilo prakse u informacijskim ustanovama }\end{array}$ & 2,70 & 68,1 & 50,6 & 0,005 \\
\hline
\end{tabular}

Na kraju ovog bloka pitanja od ispitanika je traženo da ocijene razinu svog zadovoljstva trima glavnim karakteristikama studija (tablica 15.), samim studijskim programom, praksom i nastavnicima. Opće su ocjene u skladu s ranije prikazanim rezultatima i ne prelaze ocjenu 4, a zadovoljstvo praksom ponovo je na negativnom dijelu skale.

Tablica 15. Opće zadovoljstvo

\begin{tabular}{|c|c|c|c|c|}
\hline \multirow{2}{*}{$\begin{array}{l}\text { Procijenite Vaše ukupno zadovoljstvo sl- } \\
\text { jedećim aspektima studija koji ste završili. }\end{array}$} & & \multicolumn{2}{|c|}{ Srednji rang } & \multirow[b]{2}{*}{$\mathbf{p}$} \\
\hline & AS & Red. & Izv. & \\
\hline Studijskim programom & 3,74 & 52,5 & 70,9 & 0,002 \\
\hline Praksom & 2,95 & 60,1 & 58,8 & 0,835 \\
\hline $\begin{array}{l}\text { Nastavnicima - načinom predavanja, komu- } \\
\text { nikacijom i sl. }\end{array}$ & 3,96 & 56,0 & 65,3 & 0,124 \\
\hline
\end{tabular}

\section{Stručna zajednica i praćenje struke}

Na kraju ispitanicima je postavljeno nekoliko pitanja kojima smo željeli ispitati koliko se bivši studenti koriste mrežom poznanstava sa studija (tablica 16.), odnosno koliko su uključeni u stručnu zajednicu (tablica 17.).

Tablica 16. Korištenje mrežom poznanstava

\begin{tabular}{|l|c|c|c|c|c|c|c|c|}
\hline \multirow{4}{*}{$\begin{array}{l}\text { Koliko se koristite } \\
\text { mrežom poznansta- } \\
\text { va sa studija? }\end{array}$} & \multicolumn{4}{|c|}{$\%$} & Srednji rang & \\
\cline { 2 - 9 } & 17,4 & 24,8 & 37,2 & 14,9 & 5,8 & 64,7 & 53,7 & 0,072 \\
\cline { 2 - 9 }
\end{tabular}


Tablica 17. Članstvo u udruženjima

\begin{tabular}{|l|r|r|}
\hline Jeste li član nekog od sljedećih udruženja? & $\mathrm{n}$ & $\%$ \\
\hline Hrvatsko knjižničarsko društvo * & 44 & 55,7 \\
\hline Hrvatsko čitateljsko društvo * & 11 & 16,9 \\
\hline Hrvatsko informacijsko i dokumentacijsko društvo * & 0 & 0,0 \\
\hline Neke od komisija ili radnih grupa HKD-a ** & 9 & 20,5 \\
\hline
\end{tabular}

* Samo oni koji rade u knjižnici

** Samo oni koji su članovi HKD-a

Iz tablice 16. vidimo kako preko $60 \%$ ispitanika svoju mrežu poznanstava sa studija rabi samo rijetko ili ponekad, a tek nešto preko $20 \%$ to čini često ili vrlo često. Također je zanimljivo da je samo 55,7 \% ispitanika koji rade u knjižnicama učlanjeno u krovno strukovno udruženje, Hrvatsko knjižničarsko društvo.

Ispitanike koji rade u knjižnicama pitali smo i u kojoj mjeri prate hrvatske stručne/znanstvene časopise iz područja knjižničarstva (tablica 18.). Očekivano, u najvećoj se mjeri prate tradicionalna izdanja HKD-a, Vjesnik bibliotekara hrvatske i Novosti HKD-a, a preko dvije trećine ispitanika prati ih povremeno ili često. Časopis Libellarium prati jedva nešto preko $25 \%$ (povremeno ili često). Zanimljivo je i da glasila regionalnih društava prati relativno mali broj ispitanika, manje od polovine (povremeno ili često). Pretpostavljamo kako je razlog takvog rezultata što nemaju sva regionalna društva svoja glasila.

Tablica 18 Praćenje stručne/znanstvene literature

\begin{tabular}{|c|c|c|c|c|c|c|c|}
\hline \multirow{2}{*}{$\begin{array}{l}\text { Pratite li neku od slje- } \\
\text { deće stručne/znanstvene } \\
\text { literature? }\end{array}$} & \multicolumn{4}{|c|}{$\%$} & \multicolumn{2}{|c|}{$\begin{array}{l}\text { Srednji } \\
\text { rang }\end{array}$} & \multirow[b]{2}{*}{$\mathbf{p}$} \\
\hline & Nikada & Rijetko & Povremeno & Često & Red. & Izv. & \\
\hline $\begin{array}{l}\text { Vjesnik bibliotekara } \\
\text { Hrvatske }\end{array}$ & 12,7 & 17,7 & 41,8 & 27,8 & 56,3 & 66,0 & 0,149 \\
\hline Libellarium & 47,4 & 25,6 & 21,8 & 5,1 & 35,4 & 42,4 & 0,788 \\
\hline Novosti HKD-a & 14,1 & 16,7 & 41,0 & 28,2 & 37,8 & 39,1 & 0,081 \\
\hline $\begin{array}{l}\text { Glasila regionalnih knjižni- } \\
\text { čarskih društava }\end{array}$ & 30,8 & 24,4 & 28,2 & 16,7 & 34,1 & 42,5 & 0,023 \\
\hline
\end{tabular}




\section{Rasprava}

Mišljenja završenih studenata jedni su od ključnih podataka koji se rabe u svrhu izrade i unaprjeđivanja studijskih programa studija informacijskih znanosti/ knjižničarstva. Bivši studenti, bez obzira jesu li zaposleni ili ne, mogu objektivnije, s vremenskim odmakom, procijeniti program koji su svladali. Dodatno, oni koji rade imaju prilike u stvarnoj situaciji procjenjivati koliko im znanja stečena na studiju pomažu u obavljanju svakodnevnih poslova.

Kao što je vidljivo iz rezultata, motivi upisa studenata na studij informacijskih znanosti/knjižničarstva većinom su pozitivni u smislu da su uglavnom upisivali studij u području kojim se žele baviti. Očekivano, kod izvanrednih studenata češći je slučaj upisivanja studija nakon što su se „nekako našli u knjižnici“, ali, ukupno gledano, u promatranom uzorku takvih slučajeva relativno je malo. U skladu je s takvom slikom i procjena zadovoljstva ispitanika radnim mjesto koje je s ocjenom 4,21 čvrsto na pozitivnom dijelu skale. S druge strane ocjena korisnosti znanja i vještina u svakodnevnom radu u knjižnici, a koje su stekli na studiju relativno je niskih 3,79. Ocjene dobivenih pojedinačnih općih i knjižničarskih kompetencija uglavnom se kreću između neutralnog i prvog pozitivnog stupnja skale. Ukoliko tim rezultatima pridodamo i nisku ocjene prakse $(2,95)$, koja je sastavni dio nastavnih programa, možemo zaključiti kako postoji prostor za unapređenje. Studijski programi streme tome da budu aktualni i da osposobe kompetentne stručnjake. Međutim rezultati ovog istraživanja ukazuju na diskrepanciju na koju je već upozorila Machala ${ }^{44}$ - između kompetencija koja su visoko vrednovane od strane praktičara u odnosu na one koje bi po mišljenju profesora trebale biti visoko vrednovane. Jedna od vještina koja je dobila visoku ocjenu u odnosu na druge, a koja je ključna za rad u knjižnici danas, vještine su pretraživanja i vrednovanja informacija $(4,10)$. S druge strane ukoliko znamo da je u svim tipovima knjižnica organiziran velik broj tečajeva informacijskog opismenjavanja s jedne strane i s obzirom na objektivnu potrebu poučavanja korisnika s druge strane te niz „,zamki“ informacija oko nas danas, poput aktualnog fenomena lažnih vijesti i tome slično, niske ocjene za sposobnost poučavanja korisnika $(3,32)$, znanje pedagogije i metodike poučavanja $(2,61)$ upućuju na potrebu jačanja programa i studentskih aktivnosti u tom smjeru.

U praksi, u knjižnicama svih tipova knjižničari organiziraju velik broj raznolikih događanja i programa kojima, između ostaloga, promoviraju knjižnicu u zajednici u kojoj djeluje. Ispitanici su dali vrlo nisku ocjenu sposobnostima organizacije i izvođenja programa iz kulture $(2,78)$, što u kombinaciji s ocjenom 3,41 za vještine i sposobnost javnog komuniciranja i djelovanja ukazuje na nedovoljnu potporu postojećoj knjižničnoj praksi u tom segmentu. Kompetencije vezane uz izgradnju digitalnih zbirki i stvaranja novog znanja danas su ključne u informacij-

44 Isto, str. 227. 
skim ustanovama, a napose knjižnicama. Iz redova predavanja svih triju odsjeka/ odjela vidljivo je da postoje predmeti koji se bave tim područjem, ali pitanje je koliko su studenti nakon završetka studija zbilja samostalni u izvršavanju tih zadataka. Ocjena na čestici Znanja $i$ vještine upravljanja procesima digitalizacije $(3,19)$ također ukazuje da ima prostora za poboljšanje.

Pri analizi rezultata mora se uzeti u obzir kako je cilj svih triju, ovim radom obuhvaćenih, studija informacijskih znanosti/knjižničarstva studentima tijekom tri ili pet godina omogućiti uvid u najnovija teorijske spoznaje iz područja informacijskih znanosti, slijediti trendove u području knjižničarstva i pripremiti ih za budući posao. Međutim i poslodavci i studenti moraju prihvatiti kako je potrebno vrijeme za privikavanje na posao i upoznavanje s poslovnim procesima te da za primjenu znanja i vještina koje steknu na studiju treba vremena. Drugim riječima, glavni cilj studijskih programa informacijskih znanosti/knjižničarstva uvijek će biti davanje teorijskog temelja koji će omogućiti kvalitetnu nadgradnju u situaciji konkretnog zaposlenja i poslova koji se obavljaju te stoga možemo pretpostaviti kako relativno slabi rezultati ocjena dobivenih kompetencija barem dijelom mogu proizlaziti iz različite percepcije željenih ishoda studijskih programa. U prilog toj tezi idu i razlike primijećene između redovitih i izvanrednih studenata. Statistički značajnih razlika između tih dviju grupa nema puno, no tamo gdje se razlike pokazuju, redoviti studenti daju više ocjene. Razlog tomu može biti i razlika u režimu studiranja, no možemo pretpostaviti kako izvanredni studenti imaju nešto drugačija očekivanja od studija. Prilikom ocjenjivanja studija u većoj su mjeri okrenuti poslovima s kojima se svakodnevno susreću, što neminovno mora imati utjecaja i na očekivanja od studija.

Završetkom studija informacijskih znanosti/knjižničarstva i zaposlenjem u knjižnici bivši studenti započinju novi ciklus u svom obrazovanju, a to je stalno stručno usavršavanje. Nije potrebno naglašavati važnost stalnog stručnog usavršavanja i izgradnje mreže poznanstava koje su nužne za stručno napredovanje, a u izgradnji te mreže važnu ulogu mogu imati alumni-klubovi. Pojava alumni-klubova u hrvatskom visokoškolskom sustavu novijeg je datuma. Međutim, u praksi, alumni-klubovi tek se moraju osnažiti, bolje organizirati kako bi bivši i sadašnji studenti, ali i odjeli/odsjeci prepoznali prednosti i mogućnosti koje im takvi klubovi omogućavaju. Osim što bivši studenti mogu biti jedni od najboljih zagovaratelja (pri lobiranju) odjela/odsjeka, važna je njihova uloga pri umrežavanju bivših kolega.

U tom kontekstu zabrinjavajuć je mali postotak ispitanika koji su članovi Hrvatskog knjižničarskog društva. Neki su od ciljeva, važnih u ovom kontekstu, koje Hrvatsko knjižničarsko društvo navodi u svom poslanju ${ }^{45}$,promicati i unapređivati knjižničarsku struku i na odgovarajući je način predstavljati u javnosti, zalagati

45 Poslanje. [citirano: 2019-09-28.]. Dostupno na: http://hkdrustvo.hr/hr/o_nama/poslanje/. 
se za profesionalni integritet knjižničnih djelatnika, osiguravati slobodan protok informacija, kako bi se svim građanima omogućio i olakšao slobodan i jednak pristup građi i informacijama, zastupati pravo korisnika knjižničnih usluga i službi na slobodan i jednak pristup građi i informacijama, promicati opću pismenost, širiti svijest o potrebi čuvanja kulturne baštine i sudjelovati u njezinoj zaštiti“. Tijekom studija studenti se upoznaju s tim ciljevima i obrazuju se kao budući profesionalci koji će štititi dignitet struke te kroz svoj rad jačati struku kako prema kolegama tako i prema široj zajednici.

\section{Zaključak}

Kao što se moglo vidjeti iz rezultata istraživanja, postoji svojevrsni raskorak između ishoda učenja i kompetencija koje se očekuju da će ih studenti imati završetkom studija i percepcije studenata o razini dobivenih kompetencija. Očekivanja poslodavaca, kao što je Dijana Machala naglasila u svojem istraživanju, nisu uvijek ono što studijski programi obuhvaćaju. Samo postojanje razlike u percepciji ne znači nužno i da su kompetencije koje studenti dobiju završetkom studija manjkave. Studijski programi uvijek će obuhvaćati veću teorijsku širinu nego što će prosječnom završenom studentu u konkretnom poslu biti potrebno. Osim toga provedeno istraživanje nije uzelo u obzir uspješnost studenata tijekom studija. Može se pretpostaviti da će uspješnost tijekom studija biti varijabla koja može utjecati na percepciju dobivenih kompetencija. Ipak, ne može se zanijekati činjenica kako razlika između kompetencija koje studijski programi nude i percepcije dobivenih kompetencija postoji, što vrlo vjerojatno znači da prostora za poboljšanje ima, kako u pogledu studijskih programa tako i u pogledu budućih istraživanja kojima bi se uočeni rezultat dodatno dublje istražio. Mišljenja završenih studenata jedna su od ključnih informacija koje nastavnici moraju uzimati u obzir pri izradi novih studijskih programa. Dubinskim intervjuima moguće je dobiti cjelovitiju sliku zadovoljstva ili nezadovoljstva stečenim znanjem i dobivenim kompetencijama pa se može pretpostaviti da će autori razvijati istraživanje u tom smjeru. Kao što je istaknuto u zaključku istraživanja, oni koji imaju priliku raditi u knjižnici nalaze se u stvarnim situacijama u kojima mogu procijeniti koliko im znanja stečena na studiju pomažu pri obavljanju svakodnevnih poslova. No moglo bi se argumentirati da samo oni knjižničari koji sustavno ulažu u svoj stručni razvoj, prate stručnu literaturu i sudjeluju u programima cjeloživotnog obrazovanja mogu biti u stanju objektivno procijeniti koja je znanja i vještine potrebno mijenjati u razvoju studijskih programa koji obrazuju buduće kolege knjižničare. 


\section{LITERATURA}

Alumni. [citirano: 2019-09-15.]. Dostupno na: www.ffos.unios.hr/infoznanosti/alumni

Alumni Filozofskog fakulteta. [citirano: 2019-09-15.]. Dostupno na: www.ffzg.org.

Barbarić, A. Knjižničarske kompetencije. // Cjeloživotno učenje knjižničara: ishodi učenja i fleksibilnost / urednice Aleksandra Horvat i Dijana Machala. Zagreb: Nacionalna i sveučilina knjižnica u Zagrebu, 2009. Str. 57-68. [citirano: 2019-09-20.] Dostupno na: https://www.nsk.hr/cuk/cuk.pdf.

Bishop B.W.; A. W. Cadle; T. H. Grubisic. Job analses of emerging information professions: a survey validation of core competencies to inform curricula. // Library Quarterly Information, Community Policy 85, 1(2015), 64-84. [citirano: 2020-10-03]. Dostupno na: https://doi.org/10.1086/679026.

CUK: cjeloživotno učenje knjižničara: ishodi učenja i fleksibilnosti. [citirano: 2019-0917.]. Dostupno na: http://www.nsk.hr/cuk/index.htm.

Hrvatski kvalifikacijski okvir (HKO). [citirano: 2019-09-20.]. Dostupno na: https:// www.azvo.hr/hr/ured-enic-naric/hrvatski-kvalifikacijski-okvir-hko.

ECTS Informacijski paket za akademsku godinu 2019./2020.: Informacijske znanosti, diplomski. [citirano: 2019-09-25.]. Dostupno na: http://theta.ffzg.hr/ECTS/Studij/ Index/4447.

ECTS Informacijski paket za akademsku godinu 2019./2020.: Informacijske znanosti, preddiplomski. [citirano: 2019-09-25.]. Dostupno na: http://theta.ffzg.hr/ECTS/Stu$\mathrm{dij} /$ Index/928

ECTS Informacijski paket za akademsku godinu 2019./2020.: Informacijske znanosti, smjer Bibliotekarstvo, dvopredmetni. [citirano: 2019-09-25.]. Dostupno na: http:// theta.ffzg.hr/ECTS/Studij/Index/1175

ECTS Informacijski paket za akademsku godinu 2019./2020.: Informacijske znanosti, smjer Bibliotekarstvo, jednopredmetni. [citirano: 2019-09-25.]. Dostupno na: http:// theta.ffzg.hr/ECTS/Studij/Index/1170

Faletar Tanacković, S.; J. Žilić; S. Kurbanoglu; Y. Unal. Student perceptions of LIS programs and profession: Study among undergraduates in Croatia and Turkey. // The Future of Education in Information Science: Proceedings from FEIS - International EINFOSE Symposium 10-11 September 2018 Pisa, Italy / ed. by Tatjana Aparac-Jelušić, Vittore Casarosa, and Elena Macevičiūtè. Osijek: Faculty of Humanities and Social Sciences, University of Osijek, 2018. Str. 46-61. [citirano: 2020-10-03]. Dostupno na: http://einfose.ffos.hr/feis-2018/proceedings

Ishodi učenja: Merlin 17/18. [citirano: 2019-09-17.]. Dostupno na: https://wiki.srce.hr/ pages/viewpage.action?pageId $=10551508$

Jozinović, T. Spremnost magistara informatologije Odsjeka za informacijske znanosti u Osijeku za tržište rada: diplomski rad. Osijek: Filozofski fakultet, 2015. 
Lončar-Vicković, S.; Z. Dolaček-Alduk. Ishodi učenja: priručnik za sveučilišne nastavnike. Osijek: Sveučilište Josipa Jurja Strossmayera, 2009. [citirano: 2019-09-20.]. Dostupno na: https://www.azoo.hr/images/natjecanja_2014./ishodi_ucenja.pdf.

Machala, D. Knjižničarske kompetencije: pogled na razvoj profesije. Zagreb: Hrvatska sveučilišna naklada: Nacionalna i sveučilišna knjižnica, 2015.

Novi revidirani program „Informacijske znanosti“ - diplomski studij. [citirano: 201909-25.]. Dostupno na: http://iz.unizd.hr/Portals/70/docs_stari_web/Diplomski_revidirani_program_informacijske_znanosti_2015-16_HRV.pdf

Novi revidirani program „Informacijske znanosti“ - preddiplomski studij. [citirano: 2019-09-25.]. Dostupno na: http://iz.unizd.hr/Portals/70/docs_stari_web/Preddiplomski_revidirani_program_informacijske_znanosti_2015-16_HRV.pdf

Odjel za informacijske znanosti. [citirano: 2019-09-25.]. Dostupno na: https://inf.ffzg. unizg.hr/index.php/hr/

Odjel za informacijske znanosti: samoanaliza (2014). [citirano: 2019-09-25.]. Dostupno na: http://iz.unizd.hr/Portals/70/docs_stari_web/sa_starog_weba_ZG/SAMOANALIZA_OIZ_FIN_potpis.pdf

Odsjek za informacijske i komunikacijske znanosti Filozofskog fakulteta Sveučilišta u Zagrebu. / uredila Jadranka Lasić-Lazić. Zagreb : Zavod za informacijske studije, 2013.

Odsjek za informacijske znanosti - Elaborati studijskih programa. [citirano: 2019-0920.]. Dostupno na: https://sokrat.ffos.hr/oziz/elaborati/

Poslanje. [citirano: 2019-09-28.]. Dostupno na: http:/hkdrustvo.hr/hr/o_nama/poslanje/

Petr Balog, K. Ishodi učenja Odsjeka za informacijske znanosti u Osijeku - rezultati istraživanja. // Ishodi učenja: priručnik za sveučilišne nastavnike / Sanja Lončar-Vicković, Zlata Dolaček-Alduk (ur.). Osijek: Sveučilište Josipa Jurja Strossmayera, 2009. Str. 103-117. [citirano: 2019-09-22.]. Dostupno na: https:/www.azoo.hr/images/Natjecanja_2014./ishodi_ucenja.pdf.

Petr Balog, K.; I. Martinović. Na tragu ishoda učenja: kompetencije diplomiranih knjižničara Odsjeka za informacijske znanosti u Osijeku. // Vjesnik bibliotekara Hrvatske 52, 1/4 (2009), 1-17. [citirano: 2019-09-20.]. Dostupno: https://www. hkdrustvo.hr/vjesnik-bibliotekara-hrvatske/index.php/vbh/article/view/457

Povijest: Odsjek za informacijske znanosti. [citirano: 2019-09-20.] Dostupno na: https:// www.ffos.unios.hr/infoznanosti/povijest

Povijest nastanka Odsjeka. [citirano: 2019-09-25.]. Dostupno na: https://inf.ffzg.unizg. hr/index.php/hr/odsjek/povijest-nastanka-odsjeka

Pravilinik o mjerilima i kriterijima za vrednovanje kvalitete i učinkovitosti visokih učilišta i studijskih programa. // Narodne novine 9, 139(2005). [citirano: 2019-09-15.]. Dostupno na: https://narodne-novine.nn.hr/clanci/sluzbeni/2005_01_9_139.html. 
Priručnik kvalitete na Sveučilištu u Zadru (Zadar, 2012). [citirano: 2019-09-15.] - Dostupno na: www.unizd.hr/Portals/0/kvaliteta/Priručnik_kvalitete.pdf

Program studija. [citirano: 2019-09-25.]. Dostupno na: http://iz.unizd.hr/language/enus/studijski-programi/preddiplomski-studij

Provjera osiguranja kvalitete na visokim učilištima [citirano: 2019-09-10.] Dostupno na: http://forum.azvo.hr/cd/LinkedDocuments/AZVO_Provjera_osiguranja_kvalitete_Petrovic\% $\% 20-\% 20$ presentation.pdf

Saunders, L. Core and more: examining foundational and specialized content in library and information science. // Journal of Education for Library and Information Science 60 1(2019), 3-34. [citirano: 2020-10-03]. Dostupno na: https://doi.org/10.3138/ jelis.60.1.2018-0034

Statut Alumni kluba Sveučilišta u Zadru [citirano: 2019-09-15.]. Dostupno na: http://www.unizd.hr/Portals/0/alumni_klub/Statut_Alumni_kluba. pdf?ver=2014-12-10-133738-453

Studijski program. [citirano: 2019-09-25.]. Dostupno na: http://iz.unizd.hr/studijski-programi.

Smjernice za razvoj standarda kvalifikacija. [citirano: 2019-09-20.]. Dostupno na: http:// www.kvalifikacije.hr/sites/default/files/documents-publications/2019-08/Smjernice\%20za\%20razvoj\%20standarda\%20kvalifikacija.pdf 


\section{Prilog 1. Anketni upitnik}

\section{Alumni}

\section{Poštovani,}

upitnik koji je pred Vama dio je istraživanja stavova i zadovoljstva bivših studenata studijskim programima odsjeka/odjela informacijskih znanosti u Hrvatskoj. Molimo Vas da odvojite vrijeme za pažljivo čitanje upitnika i odgovaranje na sva postavljena pitanja. Sudjelovanje u ovom istraživanju u potpunosti je anonimno, a dobiveni podaci rabit će se isključivo u istraživačke svrhe. Potrebno je vrijeme za ispunjavanje upitnika oko 10 minuta.

U slučaju bilo kakvih pitanja: boris.badurina@ffos.hr Postoji 32 pitanja u ovom upitniku.

1. Molimo, navedite kojeg ste spola?

Molimo, izaberite samo jedan od ponuđenih odgovora.

ženskog

muškog

2. Koliko imate godina?

U ovo polje mogu biti upisani samo brojevi.

Molimo, unesite svoj odgovor ovdje:

3. Molimo, navedite u kojem mjestu (gradu) radite.

Molimo, unesite svoj odgovor ovdje:

4. U kojem ste obliku završili studij? Ukoliko ste završili više od jednog studija, molimo, navedite odgovor za studij knjižničarstva/informacijskih znanosti.

Izaberite jedan od ponuđenih odgovora.

Molimo, izaberite samo jedan od ponuđenih odgovora.

Redovni studij (knjižničarstvo, bilbliotekarstvo, informacijske znanosti)

Izvanredni studij (knjižničarstvo, bilbliotekarstvo, informacijske znanosti)

Neki drugi studij

5. Koje ste godine (kalendarske) završili studij u polju knjižničarstva/informacijskih znanosti?

U ovo polje mogu biti upisani samo brojevi.

Molimo, unesite svoj odgovor ovdje: 
6. Zašto ste se odlučili za studij knjižničarstva/informacijskih znanosti? Molimo, navedite u kojoj se mjeri slažete s niže navedenim tvrdnjama.

Molimo, izaberite odgovarajući odgovor za svaku stavku.

\begin{tabular}{|l|c|c|c|c|c|}
\hline & $\begin{array}{c}\text { Uopće } \\
\text { se ne } \\
\text { slažem }\end{array}$ & $\begin{array}{c}\text { Djelomič- } \\
\text { no se ne } \\
\text { slažem }\end{array}$ & $\begin{array}{c}\text { Niti se } \\
\text { slažem niti } \\
\text { ne slažem }\end{array}$ & $\begin{array}{c}\text { Djelo- } \\
\text { mično se } \\
\text { slažem }\end{array}$ & $\begin{array}{c}\text { U pot- } \\
\text { punosti } \\
\text { se slažem }\end{array}$ \\
\hline $\begin{array}{l}\text { Želio/la sam studirati } \\
\text { knjižničarstvo/informacij- } \\
\text { ske znanosti }\end{array}$ & $\square$ & $\square$ & $\square$ & $\square$ & $\square$ \\
\hline $\begin{array}{l}\text { Želio/la sam raditi u } \\
\text { knjižnici }\end{array}$ & $\square$ & $\square$ & $\square$ & $\square$ & $\square$ \\
\hline $\begin{array}{l}\text { Radio/la sam u knjižnici, } \\
\text { ali nisam imao/la odgova- } \\
\text { rajuću stručnu spremu }\end{array}$ & $\square$ & $\square$ & $\square$ & $\square$ & $\square$ \\
\hline $\begin{array}{l}\text { Očekivao/la sam radno } \\
\text { mjesto u knjižnici }\end{array}$ & $\square$ & $\square$ & $\square$ & $\square$ & $\square$ \\
\hline $\begin{array}{l}\text { Mislio/la sam da ću se } \\
\text { lako zaposliti u knjižnici/ } \\
\text { informacijskoj ustanovi }\end{array}$ & $\square$ & $\square$ & $\square$ & $\square$ & $\square$ \\
\hline $\begin{array}{l}\text { Zanimalo me područje } \\
\text { informacijskih znanosti }\end{array}$ & $\square$ & $\square$ & $\square$ & $\square$ & $\square$ \\
\hline $\begin{array}{l}\text { Moji prijatelji studirali } \\
\text { su na istoj grupi pa sam } \\
\text { došao/la i ja }\end{array}$ & $\square$ & $\square$ & $\square$ & $\square$ & $\square$ \\
\hline $\begin{array}{l}\text { Nisam znao/la koju grupu } \\
\text { odabrati pa sam se upisao/ } \\
\text { la na knjižnčarstvo/infor- } \\
\text { macijske znanosti }\end{array}$ & $\square$ & $\square$ & $\square$ & $\square$ & $\square$ \\
\hline $\begin{array}{l}\text { Želio/la sam drugu grupu, } \\
\text { ali nisam upisao/la }\end{array}$ & $\square$ & $\square$ & $\square$ & $\square$ & $\square$ \\
\hline $\begin{array}{l}\text { Čuo/la sam kako je to } \\
\text { lagano studirati }\end{array}$ & $\square$ & $\square$ & $\square$ & $\square$ & $\square$ \\
\hline $\begin{array}{l}\text { Mislio/la sam kako je to } \\
\text { perspektivno područje i } \\
\text { da ću lako pronaći posao }\end{array}$ & $\square$ & $\square$ & $\square$ & $\square$ & $\square$ \\
\hline
\end{tabular}


7. Jeste li zaposleni?

Izaberite jedan od ponuđenih odgovora.

Molimo, izaberite samo jedan od ponuđenih odgovora.

$\square \quad$ Da, za stalno

口 Da, na određeno

$\square \quad$ Da, na zamjeni

Na stručnom osposobljavanju za rad bez zasnivanja radnog odnosa

口 Nisam zaposlen/a

8. Gdje ste zaposleni?

Izaberite jedan od ponuđenih odgovora

Molimo, izaberite samo jedan od ponuđenih odgovora.

U knjižnici

$\square \quad$ U drugoj informacijskoj ustanovi (arhiv, muzej...)

U informatičkoj tvrtki

○ U nakladničkoj kući

$\square \quad$ Negdje drugdje, gdje?

9. U kojoj ste knjižnici zaposleni?

Odgovori samo ako su sljedeći uvjeti zadovoljeni:

Answer was 'U knjižnici' at question '8 [p9]' (Gdje ste zaposleni?)

Izaberite jedan od ponuđenih odgovora

Molimo, izaberite samo jedan od ponuđenih odgovora.

口 U osnovnoškolskoj knjižnici

U srednjoškolskoj knjižnici

U visokoškolskoj knjižnici

U narodnoj knjižnici

口 U specijalnoj knjižnici

口 U sveučilišnoj knjižnici

$\square$ U NSK-u

口 U GISKO-u 
10. Koliko imate godina radnog staža u knjižničarstvu?

Odgovorite samo ako su sljedeći uvjeti zadovoljeni:

Answer was 'U knjižnici' at question ' 8 [p9]' (Gdje ste zaposleni?)

U ovo polje mogu biti upisani samo brojevi.

Molimo, unesite svoj odgovor ovdje:

11. U kojoj ste mjeri zadovoljni svojim radnim mjestom?

Molimo, izaberite odgovarajući odgovor za svaku stavku.

\begin{tabular}{|c|c|c|c|c|}
\hline $\begin{array}{c}\text { U potpunosti } \\
\text { nezadovoljan/a }\end{array}$ & $\begin{array}{c}\text { Djelomično } \\
\text { nezadovoljan/a }\end{array}$ & $\begin{array}{c}\text { Niti zadovo- } \\
\text { ljan/a niti neza- } \\
\text { dovoljan/a }\end{array}$ & $\begin{array}{c}\text { Djelomično } \\
\text { zadovoljan/a }\end{array}$ & $\begin{array}{c}\text { Potpuno zado- } \\
\text { voljan/a }\end{array}$ \\
\hline$\square$ & $\square$ & $\square$ & $\square$ & $\square$ \\
\hline
\end{tabular}

12. U kojoj su Vam mjeri znanja i vještine stečene na studiju korisne pri radu u knjižnici?

\section{Odgovorite samo ako su sljedeći uvjeti zadovoljeni:}

Answer was 'U knjižnici' at question ' 8 [p9]' (Gdje ste zaposleni?)

Molimo, izaberite odgovarajući odgovor za svaku stavku.

\begin{tabular}{|c|c|c|c|c|}
\hline $\begin{array}{c}\text { Uopće nisu } \\
\text { korisne }\end{array}$ & $\begin{array}{c}\text { Uglavnom nisu } \\
\text { korisne }\end{array}$ & $\begin{array}{c}\text { Niti jesu niti } \\
\text { nisu korisne }\end{array}$ & $\begin{array}{c}\text { Uglavnom jesu } \\
\text { korisne }\end{array}$ & $\begin{array}{c}\text { U potpunosti } \\
\text { su korisne }\end{array}$ \\
\hline$\square$ & $\square$ & $\square$ & $\square$ & $\square$ \\
\hline
\end{tabular}

13. Molimo, procijenite u kojoj ste mjeri na studiju dobili sljedeće knjižničarske kompetencije.

\section{Odgovorite samo ako su sljedeći uvjeti zadovoljeni:}

Answer was 'U knjižnici' at question ' 8 [p9]' (Gdje ste zaposleni?)

Molimo, izaberite odgovarajući odgovor za svaku stavku.

\begin{tabular}{|l|c|c|c|c|c|}
\hline & $\begin{array}{c}\text { Uopće } \\
\text { nisam } \\
\text { dobio/la }\end{array}$ & $\begin{array}{c}\text { Uglavnom } \\
\text { nisam } \\
\text { dobio/la }\end{array}$ & $\begin{array}{c}\text { Niti jesam } \\
\text { niti nisam } \\
\text { dobio/la }\end{array}$ & $\begin{array}{c}\text { Uglavnom } \\
\text { jesam } \\
\text { dobio/la }\end{array}$ & $\begin{array}{c}\text { U pot- } \\
\text { punosti sam } \\
\text { dobio/la }\end{array}$ \\
\hline $\begin{array}{l}\text { Vještine pretraživanja } \\
\text { i vrednovanja infor- } \\
\text { macija }\end{array}$ & $\square$ & $\square$ & $\square$ & $\square$ & $\square$ \\
\hline $\begin{array}{l}\text { Učinkovito pružanje } \\
\text { informacija za potrebe } \\
\text { korisnika }\end{array}$ & $\square$ & $\square$ & $\square$ & $\square$ & $\square$ \\
\hline
\end{tabular}




\begin{tabular}{|c|c|c|c|c|c|}
\hline & $\begin{array}{l}\text { Uopće } \\
\text { nisam } \\
\text { dobio/la }\end{array}$ & $\begin{array}{l}\text { Uglavnom } \\
\text { nisam } \\
\text { dobio/la } \\
\end{array}$ & $\begin{array}{c}\text { Niti jesam } \\
\text { niti nisam } \\
\text { dobio/la }\end{array}$ & $\begin{array}{l}\text { Uglavnom } \\
\text { jesam } \\
\text { dobio/la }\end{array}$ & \begin{tabular}{|c|} 
U pot- \\
punosti sam \\
dobio/la \\
\end{tabular} \\
\hline $\begin{array}{l}\text { Vještine uporabe infor- } \\
\text { macijskih pomagala i } \\
\text { izvora }\end{array}$ & $\square$ & $\square$ & $\square$ & $\square$ & $\square$ \\
\hline $\begin{array}{l}\text { Sposobnost pružanja } \\
\text { i razvijanja usluga za } \\
\text { korisnike }\end{array}$ & $\square$ & $\square$ & $\square$ & $\square$ & $\square$ \\
\hline $\begin{array}{l}\text { Znanje i primjena } \\
\text { izgradnje i upravljanja } \\
\text { zbirkama }\end{array}$ & $\square$ & $\square$ & $\square$ & $\square$ & $\square$ \\
\hline $\begin{array}{l}\text { Znanje i primjena } \\
\text { izgradnje i upravljanja } \\
\text { digitalnim zbirkama }\end{array}$ & $\square$ & $\square$ & $\square$ & $\square$ & $\square$ \\
\hline $\begin{array}{l}\text { Znanje i sposobnost } \\
\text { sadržajne obrade građe }\end{array}$ & $\square$ & $\square$ & $\square$ & $\square$ & $\square$ \\
\hline $\begin{array}{l}\text { Razumijevanje zakon- } \\
\text { skih i etičkih okvira }\end{array}$ & $\square$ & $\square$ & $\square$ & $\square$ & $\square$ \\
\hline $\begin{array}{l}\text { Znanje i sposobnost } \\
\text { formalne obrade građe }\end{array}$ & $\square$ & $\square$ & $\square$ & $\square$ & $\square$ \\
\hline $\begin{array}{l}\text { Sposobnost upravljanja } \\
\text { i uporabe informaci- } \\
\text { jskih tehnologija }\end{array}$ & $\square$ & $\square$ & $\square$ & $\square$ & $\square$ \\
\hline $\begin{array}{l}\text { Vještine i sposobnost } \\
\text { javnog komuniciranja i } \\
\text { djelovanja }\end{array}$ & $\square$ & $\square$ & $\square$ & $\square$ & $\square$ \\
\hline $\begin{array}{l}\text { Sposobnost poučavanja } \\
\text { korisnika }\end{array}$ & $\square$ & $\square$ & $\square$ & $\square$ & $\square$ \\
\hline $\begin{array}{l}\text { Upravljanje procesima } \\
\text { informatizacije kn- } \\
\text { jižničnog poslovanja } \\
\text { (OPAC, knjižnični } \\
\text { sustav) }\end{array}$ & $\square$ & $\square$ & $\square$ & $\square$ & $\square$ \\
\hline $\begin{array}{l}\text { Znanje i primjena is- } \\
\text { traživačkih metoda }\end{array}$ & $\square$ & $\square$ & $\square$ & $\square$ & $\square$ \\
\hline $\begin{array}{l}\text { Znanje i primjena pos- } \\
\text { tupaka zaštite i pohrane } \\
\text { građe }\end{array}$ & $\square$ & $\square$ & $\square$ & $\square$ & $\square$ \\
\hline
\end{tabular}




\begin{tabular}{|l|c|c|c|c|c|}
\hline & $\begin{array}{c}\text { Uopće } \\
\text { nisam } \\
\text { dobio/la }\end{array}$ & $\begin{array}{c}\text { Uglavnom } \\
\text { nisam } \\
\text { dobio/la }\end{array}$ & $\begin{array}{c}\text { Niti jesam } \\
\text { niti nisam } \\
\text { dobio/la }\end{array}$ & $\begin{array}{c}\text { Uglavnom } \\
\text { jesam } \\
\text { dobio/la }\end{array}$ & $\begin{array}{c}\text { U pot- } \\
\text { punosti sam } \\
\text { dobio/la }\end{array}$ \\
\hline $\begin{array}{l}\text { Znanje i primjena } \\
\text { temeljnih teorijskih } \\
\text { načela }\end{array}$ & $\square$ & $\square$ & $\square$ & $\square$ & $\square$ \\
\hline $\begin{array}{l}\text { Znanja i vještine upra- } \\
\text { vljanja procesima digi- } \\
\text { talizacije }\end{array}$ & $\square$ & $\square$ & $\square$ & $\square$ & $\square$ \\
\hline $\begin{array}{l}\text { Znanje i sposobnost } \\
\text { stvaranja novog znanja }\end{array}$ & $\square$ & $\square$ & $\square$ & $\square$ & $\square$ \\
\hline $\begin{array}{l}\text { Znanje pedagogije i } \\
\text { metodike poučavanja }\end{array}$ & $\square$ & $\square$ & $\square$ & $\square$ & $\square$ \\
\hline $\begin{array}{l}\text { Sposobnost organizaci- } \\
\text { je i izvođenja programa } \\
\text { iz kulture }\end{array}$ & $\square$ & $\square$ & $\square$ & $\square$ & $\square$ \\
\hline $\begin{array}{l}\text { Znanje i razumijevanje } \\
\text { izdavačkog procesa }\end{array}$ & $\square$ & $\square$ & $\square$ & $\square$ & $\square$ \\
\hline
\end{tabular}

14. Molimo, procijenite u kojoj ste mjeri na studiju dobili sljedeće opće kompetencije.

Molimo, izaberite odgovarajući odgovor za svaku stavku.

\begin{tabular}{|l|c|c|c|c|c|}
\hline & $\begin{array}{c}\text { Uopće } \\
\text { nisam } \\
\text { dobio/la }\end{array}$ & $\begin{array}{c}\text { Uglavnom } \\
\text { nisam } \\
\text { dobio/la }\end{array}$ & $\begin{array}{c}\text { Niti jesam } \\
\text { niti nisam } \\
\text { dobio/la }\end{array}$ & $\begin{array}{c}\text { Uglavnom } \\
\text { jesam } \\
\text { dobio/la }\end{array}$ & $\begin{array}{c}\text { U pot- } \\
\text { punosti sam } \\
\text { dobio/la }\end{array}$ \\
\hline $\begin{array}{l}\text { Osnovne vještine upora- } \\
\text { be računala }\end{array}$ & $\square$ & $\square$ & $\square$ & $\square$ & $\square$ \\
\hline $\begin{array}{l}\text { Vještine prikupljanja i } \\
\text { upravljanja informaci- } \\
\text { jama }\end{array}$ & $\square$ & $\square$ & $\square$ & $\square$ & $\square$ \\
\hline $\begin{array}{l}\text { Sposobnosti za timski } \\
\text { rad }\end{array}$ & $\square$ & $\square$ & $\square$ & $\square$ & $\square$ \\
\hline Etičnost & $\square$ & $\square$ & $\square$ & $\square$ & $\square$ \\
\hline Komunikacijske vještine & $\square$ & $\square$ & $\square$ & $\square$ & $\square$ \\
\hline $\begin{array}{l}\text { Sposobnost primjene } \\
\text { teorijskog znanja u } \\
\text { praksi }\end{array}$ & $\square$ & $\square$ & $\square$ & $\square$ & $\square$ \\
\hline Samostalnost u radu & $\square$ & $\square$ & $\square$ & $\square$ & $\square$ \\
\hline
\end{tabular}




\begin{tabular}{|l|c|c|c|c|c|}
\hline & $\begin{array}{c}\text { Uopće } \\
\text { nisam } \\
\text { dobio/la }\end{array}$ & $\begin{array}{c}\text { Uglavnom } \\
\text { nisam } \\
\text { dobio/la }\end{array}$ & $\begin{array}{c}\text { Niti jesam } \\
\text { niti nisam } \\
\text { dobio/la }\end{array}$ & $\begin{array}{c}\text { Uglavnom } \\
\text { jesam } \\
\text { dobio/la }\end{array}$ & $\begin{array}{c}\text { U pot- } \\
\text { punosti sam } \\
\text { dobio/la }\end{array}$ \\
\hline $\begin{array}{l}\text { Sposobnost prilagodbe } \\
\text { novim situacijama }\end{array}$ & $\square$ & $\square$ & $\square$ & $\square$ & $\square$ \\
\hline $\begin{array}{l}\text { Organizacijske sposob- } \\
\text { nost i vještine upravljanja }\end{array}$ & $\square$ & $\square$ & $\square$ & $\square$ & $\square$ \\
\hline $\begin{array}{l}\text { Kritičke i samokritičke } \\
\text { sposobnosti }\end{array}$ & $\square$ & $\square$ & $\square$ & $\square$ & $\square$ \\
\hline Znanje stranog jezika & $\square$ & $\square$ & $\square$ & $\square$ & $\square$ \\
\hline $\begin{array}{l}\text { Istraživačke metode, } \\
\text { stručni i znanstveni rad }\end{array}$ & $\square$ & $\square$ & $\square$ & $\square$ & $\square$ \\
\hline Želja za uspjehom & $\square$ & $\square$ & $\square$ & $\square$ & $\square$ \\
\hline
\end{tabular}

15. Ukoliko ste tijekom rada u knjižnici naišli na poteškoće, kako ste ih savladali? Odgovorite samo ako su sljedeći uvjeti zadovoljeni:

Answer was 'U knjižnici' at question '8 [p9]' (Gdje ste zaposleni?)

Možete izabrati više odgovora

Molimo, izaberite sve opcije koje Vam odgovaraju.

$\square$ Potražio/la sam pomoć kolega

- Pretraživao/la sam mrežne izvore

$\square$ Konzultirao/la sam stručnu literaturu

$\square$ Obratio/la sam se voditelju Matične službe

- Obratio/la sam se svojim profesorima s fakulteta za pomoć

口 Obratio/la sam se svojim kolegama s fakulteta za pomoć

$\square$ Nekako drugačije, kako?:

16. Koliko se koristite mrežom poznanstava sa studija?

Izaberite jedan od ponuđenih odgovora

Molimo, izaberite samo jedan od ponuđenih odgovora.

$\square$ Nikada

$\square$ Rijetko

口 Ponekad

$\square$ Često

$\square$ Vrlo često 
17. Postoji li na odsjeku/odjelu na kojem ste završili studij alumni-klub?

Izaberite jedan od ponuđenih odgovora

Molimo, izaberite samo jedan od ponuđenih odgovora.

$\square \mathrm{Da}$

$\square \mathrm{Ne}$

$\square \quad$ Ne znam

18. Jeste li član alumni-kluba?

Odgovorite samo ako su sljedeći uvjeti zadovoljeni:

Answer was 'Da' at question '17 [p18]' (Postoji li na odsjeku/odjelu na kojem ste završili studij alumni-klub?)

Molimo, izaberite samo jedan od ponuđenih odgovora.

$\square \mathrm{Da}$

$\square \mathrm{Ne}$

19. Jeste li član nekog od sljedećih udruženja?

Odgovorite samo ako su sljedeći uvjeti zadovoljeni:

Answer was 'U knjižnici' at question ' 8 [p9]' (Gdje ste zaposleni?)

Molim izaberite odgovarajući odgovor za svaku stavku.

\begin{tabular}{|l|c|c|}
\hline & $\mathrm{Da}$ & $\mathrm{Ne}$ \\
\hline Hrvatsko knjižničarsko društvo (regionalno knjižničarsko društvo) & $\square$ & $\square$ \\
\hline Hrvatsko čitateljsko društvo & $\square$ & $\square$ \\
\hline Hrvatsko informacijsko i dokumentacijsko društvo & $\square$ & $\square$ \\
\hline
\end{tabular}

20. Jeste li član neke od komisija ili radnih grupa HKD-a?

Odgovorite samo ako su sljedeći uvjeti zadovoljeni:

Answer was 'U knjižnici' at question ' 8 [p9]' (Gdje ste zaposleni?) i Answer was 'Da' at question '19 [p20]' (Jeste li član nekog od sljedećih udruženja? (Hrvatsko knjižničarsko društvo (regionalno knjižničarsko društvo)))

Molimo, izaberite samo jedan od ponuđenih odgovora.

$\square \quad \mathrm{Da}$
$\square \quad \mathrm{Ne}$

21. Sudjelujete li na nekim od sljedećih oblika stalnog stručnog usavršavanja?

Odgovorite samo ako su sljedeći uvjeti zadovoljeni:

Answer was 'U knjižnici' at question '8 [p9]' (Gdje ste zaposleni?) 
Molimo, izaberite odgovarajući odgovor za svaku stavku.

\begin{tabular}{|l|c|c|c|c|}
\hline & Nikada & Rijetko & Povremeno & Često \\
\hline $\begin{array}{l}\text { Radionice Centra za stalno stručno } \\
\text { usavršavanje knjižničara - CSSU }\end{array}$ & $\square$ & $\square$ & $\square$ & $\square$ \\
\hline Konferencije, seminari i sl. & $\square$ & $\square$ & $\square$ & $\square$ \\
\hline $\begin{array}{l}\text { Tutorijali, mrežni seminari (webina- } \\
\text { ri) i drugi oblici učenja na daljinu }\end{array}$ & $\square$ & $\square$ & $\square$ & $\square$ \\
\hline
\end{tabular}

22. Planirate li daljnje školovanje u području informacijskih znanosti (poslijediplomski studij u Hrvatskoj ili inozemstvu)?

Molimo, izaberite samo jedan od ponuđenih odgovora.

$\square \mathrm{Da}$

$\square \mathrm{Ne}$

23. Pratite li neku od sljedeće stručne/znanstvene literature?

Odgovorite samo ako su sljedeći uvjeti zadovoljeni:

Answer was 'U knjižnici' at question ' 8 [p9]' (Gdje ste zaposleni?)

Molimo, izaberite odgovarajući odgovor za svaku stavku.

\begin{tabular}{|l|c|c|c|c|}
\hline & Nikada & Rijetko & Povremeno & Često \\
\hline Vjesnik bibliotekara Hrvatske & $\square$ & $\square$ & $\square$ & $\square$ \\
\hline Libellarium & $\square$ & $\square$ & $\square$ & $\square$ \\
\hline Novosti HKD-a & $\square$ & $\square$ & $\square$ & $\square$ \\
\hline $\begin{array}{l}\text { Glasila regionalnih kn- } \\
\text { jižničarskih društava }\end{array}$ & $\square$ & $\square$ & $\square$ & $\square$ \\
\hline Nešto drugo & $\square$ & $\square$ & $\square$ & $\square$ \\
\hline
\end{tabular}

24. U prethodnom pitanju naveli ste da pratite neku drugu literaturu. Molimo, navedite koju.

\section{Odgovorite samo ako su sljedeći uvjeti zadovoljeni:}

Answer was 'U knjižnici' at question '8 [p9]' (Gdje ste zaposleni?) i Answer was greater than or equal to 'Rijetko' at question '23 [p24]' (Pratite li neku od sljedeće stručno/znanstvene literature? (Nešto drugo))

Molimo, unesite svoj odgovor ovdje: 
25. Sudjelujete li na konferencijama i/ili seminarima koje se održavaju u organizaciji odsjeka/odjela za informacijske znanosti u Hrvatskoj (Zagreb, Zadar, Osijek)?

Izaberite jedan od ponuđenih odgovora

Molimo, izaberite samo jedan od ponuđenih odgovora.

口 Nikada

$\square$ Rijetko

$\square$ Povremeno

Često

26. Koji su razlozi nesudjelovanja?

Odgovorite samo ako su sljedeći uvjeti zadovoljeni:

Answer was 'Nikada' at question '25 [p26]' (Sudjelujete li na konferencijama i/ili seminarima koje se održavaju u organizaciji odsjeka/odjela za informacijske znanosti u Hrvatskoj (Zagreb, Zadar, Osijek)?)

Izaberite jedan od ponuđenih odgovora

Molimo, izaberite samo jedan od ponuđenih odgovora.

$\square$ Ne zanima me

口 Preskupo je

$\square \quad$ Ne mogu odlaziti s posla

$\square$ Nešto drugo, što?

27. Pratite li rad odsjeka/odjela na kojem ste završili studij?

Izaberite jedan od ponuđenih odgovora

Molimo, izaberite samo jedan od ponuđenih odgovora.

$\square$ Nikada

$\square$ Rijetko

口 Povremeno

$\square$ Često

28. Surađujete li s nastavnicima sa studija koji ste završili i ako da, na koji način?

Molimo, unesite svoj odgovor ovdje: 
29. Procijenite koliko je na studiju koji ste završili bilo prakse u informacijskim ustanovama.

\begin{tabular}{|c|c|c|c|c|}
\hline $\begin{array}{c}\text { Potpuno ne- } \\
\text { dovoljno }\end{array}$ & $\begin{array}{c}\text { Uglavnom } \\
\text { nedovoljno }\end{array}$ & $\begin{array}{c}\text { Niti dovoljno niti } \\
\text { nedovoljno }\end{array}$ & $\begin{array}{c}\text { Uglavnom } \\
\text { dovoljno }\end{array}$ & $\begin{array}{c}\text { Potpuno } \\
\text { dovoljno }\end{array}$ \\
\hline$\square$ & $\square$ & $\square$ & $\square$ & $\square$ \\
\hline
\end{tabular}

Molimo, izaberite odgovarajući odgovor za svaku stavku.

30. S obzirom na znanja i vještine koje su danas potrebne, imate li prijedloga ili preporuka za buduće studijske programe?

Molimo, unesite svoj odgovor ovdje:

31. Procijenite Vaše ukupno zadovoljstvo sljedećim aspektima studija koji ste završili.

Molimo, izaberite odgovarajući odgovor za svaku stavku.

\begin{tabular}{|l|c|c|c|c|c|}
\hline & $\begin{array}{c}\text { U potpunosti } \\
\text { nezadovo- } \\
\text { ljan/a }\end{array}$ & $\begin{array}{c}\text { Djelomično } \\
\text { nezadovo- } \\
\text { ljan/a }\end{array}$ & $\begin{array}{c}\text { Niti zadovo- } \\
\text { ljan/a niti ne- } \\
\text { zadovoljan/a }\end{array}$ & $\begin{array}{c}\text { Djelomič- } \\
\text { no zadovo- } \\
\text { ljan/a }\end{array}$ & $\begin{array}{c}\text { U pot- } \\
\text { punosti za- } \\
\text { dovoljan/a }\end{array}$ \\
\hline $\begin{array}{l}\text { Studijskim pro- } \\
\text { gramom }\end{array}$ & $\square$ & $\square$ & $\square$ & $\square$ & $\square$ \\
\hline Praksom & $\square$ & $\square$ & $\square$ & $\square$ & $\square$ \\
\hline $\begin{array}{l}\text { Nastavnicima } \\
\text { - načinom preda- } \\
\text { vanja, komunik- } \\
\text { acijom i sl. }\end{array}$ & $\square$ & $\square$ & $\square$ & $\square$ & $\square$ \\
\hline
\end{tabular}

32. Po Vašem mišljenju, s obzirom na znanja i vještine koje ste dobili na studiju, gdje biste Vi osobno mogli raditi osim u knjižnici?

Odgovorite samo ako su sljedeći uvjeti zadovoljeni:

Answer was 'U knjižnici' at question '8 [p9]' (Gdje ste zaposleni?)

Molimo, unesite svoj odgovor ovdje:

Hvala!

Pošalji svoj upitnik.

Zahvaljujemo Vam na popunjavanju ovog upitnika. 